\title{
Evaluation of two brazilian native yeast strains (Pichia kudriavzevii) in craft beer
}

\author{
Avaliação de duas cepas de levedura nativas do brasil (Pichia kudriavzevii) em bioaromatização de \\ cerveja artesanal \\ Evaluación de dos cepas de levadura nativa del brasil (Pichia kudriavzevii) en bioaromatización de
} cerveza artesanal

\begin{abstract}
Beer production is an ancient biotechnological process and since yeast as discovered to be responsible for the transformation of barley wort into beer, studies have been carried out with the aim of understanding the behavior of these microorganisms. This work aimed to study the application of two strains of yeasts of the species Pichia kudriavzevii, isolated in the Brazilian Midwest for the production of craft beer and to analyze the occurrence of bioaromatization, with the production of volatile organic compounds (VOC) and to evaluate the sensory perception of the results with untrained end consumers through a quick sensory methodology called Check All That Apply (CATA). For this purpose, three batches of beer were produced and inoculated with commercial yeast (Saccharomyces cerevisiae, the control) and two strains of the same species, called Pichia kudriavzevii BB1 and Pichia kudriavzevii BB2. A total of 28 volatile organic compounds that differentiated the control of the Pichia BB1/BB2 group were detected, being 20 esters, 2 alcohols, 5 carboxylic acids and 1 hydrocarbon. There was no difference among the Pichia kudriavzevii $\mathrm{BB} 1$ and BB2 samples (p>0.05) in the sensory analysis using the CATA methodology. It was possible to distinguish two clusters between the tasters according to the habit of consuming craft beer, and those who consumed frequently, assigned a higher score in the hedonic test. It was concluded that Pichia kudriavzevii BB1 and BB2 influenced the beer bioaromatization, improving the acceptance test score with the tasters.
\end{abstract}

Keywords: Bioflavoring; Yeast; Volatile organic compounds; Check all that apply; Sensory analysis.

\section{Resumo}

A produção de cerveja é um processo biotecnológico milenar e, desde que se descobriu que a levedura é a responsável pela transformação do mosto de cevada em cerveja, estudos têm sido realizados com o objetivo de compreender o comportamento desses microrganismos. Este trabalho teve como objetivo estudar a aplicação de duas cepas de leveduras da espécie Pichia kudriavzevii, isoladas no Centro-Oeste brasileiro para a produção de cerveja artesanal e analisar a ocorrência de bioaromatização, com a produção de compostos orgânicos voláteis (VOC) e avaliar a percepção sensorial dos resultados com consumidores finais destreinados por meio de uma metodologia sensorial rápida chamada Check All That Apply (CATA). Para tanto, foram produzidos três lotes de cerveja inoculados com levedura comercial (Saccharomyces cerevisiae, a testemunha) e duas linhagens da mesma espécie, denominadas Pichia kudriavzevii BB1 e Pichia kudriavzevii BB2. Foram detectados 28 compostos orgânicos voláteis que diferenciaram o controle do grupo Pichia BB1 / BB2, sendo 20 ésteres, 2 álcoois, 5 ácidos carboxílicos e 1 hidrocarboneto. Não houve diferença entre as amostras de Pichia kudriavzevii BB1 e BB2 (p>0,05) na análise sensorial pela metodologia CATA. Foi possível distinguir dois clusters entre os provadores de acordo com o hábito de consumir cerveja artesanal, e os que consumiam com frequência, atribuíram maior pontuação no teste hedônico. Concluiu-se que Pichia kudriavzevii BB1 e BB2 influenciaram na bioaromatização da cerveja, melhorando a pontuação no teste de aceitação com os provadores.

Palavras-chave: Bioaromatização; Levedura; Compostos orgânicos voláteis; Marque todas as opções aplicáveis; Análise sensorial. 


\section{Resumen}

La producción de cerveza es un proceso biotecnológico ancestral y, desde que se descubrió que la levadura es la encargada de transformar el mosto de cebada en cerveza, se han realizado estudios con el objetivo de comprender el comportamiento de estos microorganismos. Este trabajo tuvo como objetivo estudiar la aplicación de dos cepas de levadura de la especie Pichia kudriavzevii, aisladas en el Medio Oeste brasileño para la producción de cerveza artesanal y analizar la ocurrencia de bioaromatización, con la producción de compuestos orgánicos volátiles (COV) y evaluar la percepción sensorial de los resultados con consumidores finales no capacitados a través de una metodología sensorial rápida llamada Check All That Apply (CATA). Para ello, se produjeron tres lotes de cerveza inoculados con levadura comercial (Saccharomyces cerevisiae, el testigo) y dos cepas de la misma especie, denominadas Pichia kudriavzevii BB1 y Pichia kudriavzevii BB2. Se detectaron 28 compuestos orgánicos volátiles que diferenciaron el control del grupo Pichia BB1 / BB2, siendo 20 ésteres, 2 alcoholes, 5 ácidos carboxílicos y 1 hidrocarburo. No hubo diferencia entre las muestras de Pichia kudriavzevii BB1 y BB2 (p>0.05) en el análisis sensorial por la metodología CATA. Se pudieron distinguir dos agrupaciones entre los catadores según su hábito de consumir cerveza artesanal, y quienes la consumieron con frecuencia obtuvieron puntuaciones más altas en la prueba hedónica. Se concluyó que Pichia kudriavzevii BB1 y BB2 influyeron en la bioaromatización de la cerveza, mejorando la puntuación en la prueba de aceptación con los catadores.

Palabras clave: Bioaromatización; Levadura; Compuestos orgánicos volátiles; Marque todas las opciones aplicables; Análisis sensorial.

\section{Introduction}

The production of beer is one of the oldest human activities. Since the Neolithic Period, 11 thousand years ago, and even before the invention of the wheel, beer has been produced and followed the progress of humanity (Zarnkow, 2014). However, it was only relatively recently that the fermentative and biotechnological process was elucidated, and it was understood that the enzymes present in malted cereals degrade starches into soluble sugars, which give rise to a watery sugar extract that will later be transformed by yeasts into alcohol and carbon dioxide (Steensels \& Vertstrepen, 2014).

Only from the middle of the year 1600, pioneering scientists like Van Leeuwenhoek began to reveal the fermentation mechanisms, opening doors to the development of pure starter cultures, and also to the selection of new superior strains that would produce desired characteristics. However, subsequent studies have shown that confinement limits microbiological diversity and reduces or limits the sensory complexity of the final product (Steensels \& Vertstrepen, 2014).

The characteristic flavor of beer is due to few ingredients, being the grains, especially the barley, responsible for providing sugar, body and flavor. Hops are responsible for bitterness and characteristic aroma compounds, while yeast produces alcohol, carbonation and hundreds of methabolic by-products (Callaway, 2016), which are complex and play an important role not only in aroma, but also in beer flavor. They impact in the quality of the final product, with the formation of a large amount of volatile compounds belonging to a variety of groups, such as estera, alcohols, acids, aldehydes, ketones, hydrocarbons, sulfuric compounds, heterocyclic compounds. The concentration, synergistic or antagonistic interactions between these substances also influence the aroma and flavor of beer (Riu-Aumatell et al., 2014).

In Brazil, beer arrived in the country for the first time in 1808, brought by the Portuguese Royal Family, and the English were the first to produce beer in Brazilian territory due to the opening of ports to so-called Friendly Nations in Portugal, (Santos, 2003). The market, which has always been dominated by large breweries, is undergoing changes with the trend of craft beer production. The growth is accelerated, and in 2018 the Ministry of Agriculture, Livestock and Supply (MAPA) registered the opening of 4 new breweries per week, reaching 889 breweries at the end of 2018. But much has to expand, since in Brazil, there is a brewery for approximately 234 thousand inhabitants (Marcusso \& Müller, 2018), while countries like the United States, have states such as California, which has more than 700 breweries and $92 \%$ of the population does not need to travel more than 16 kilometers to find a brewery (Conway, 2018).

Elzinga, Tremblay and Tremblay (2015) define the term "craft beer" as the beer associated with small-scale production, by independent producers, using traditional techniques and differentiated ingredients, giving rise to a greater range 
of beer styles, such as stout, porter, weizen, among others. A more recent study with beer consumers in Italy revealed other characteristics that define craft beer such as: made with ingredients from premium or unconventional locations, unpasteurized or unfiltered, natural and genuine, naturally or spontaneously fermented, sold in specific stores at a high cost and in small quantities, and made for a niche market (Donadini \& Porretta, 2017). These last also differentiate it from the large industry, which produces large-scale mainstream beer, mostly of a single style, using additives, preservatives or artificial ingredients.

In order to satisfy the expansion of the brewing sector, which increasingly demands more special beers, many researches have been carried out to bring more innovation to the sector and meeting specific demands of the final consumer, including finding new varieties of barley, different methods of malt production and crossing different varieties of hops. One of the main recent areas of research is the use of new yeasts, especially non-Saccharomyces, which are capable of altering the sensory profile of beer, due to characteristics such as alcohol content and concentration of acids in the final product (Capece et al., 2018; Osburn et al., 2017; Steensels \& Vertstrepen, 2014).

In view of the current scenario in the beer market globally and in Brazil, this work aimed at finding the application of new yeasts in the beer production, using yeasts present in the Yeast Storage Bank in the Bioengineering Laboratory from the Universidade Federal de Grandes Dourados (UFGD), also in Mato Grosso, Brazil, and giving continuity to a the research carried out by Camargo et al. (2018), Silvav et al. (2011).

For this purpose, a light craft beer, was developed with low bitterness, neutral characteristics, in order to highlight all flavor or aroma produced by the strains BB1 and BB2 of the species Pichia kudriavisevii, isolated by Silva, Batistote and Cereda (2011) in the municipality of Barra do Bugres - MT, in an alcohol usine. The production of bioaromas and the perception or interpretation of these by consumers through sensory analysis using the methodology Check All That Apply (CATA) was conducted.

\section{Methodology}

\subsection{Strains Origin}

The two pure strains of the Pichia kudriavzevii species, named respectively BB1 and BB2, were obtained from the Barrálcool Usine, located in the municipality of Barra do Bugres, in the state of Mato Grosso, Brazil. They were isolated by Silva et al. (2011) and physiologically described by Camargo et al. (2018), who also transferred them to the Yeast Storage Bank in the Bioengineering Laboratory from the Universidade Federal de Grandes Dourados (UFGD), also in Mato Grosso, Brazil, from where they were thawed.

\subsection{Inoculum Preparation}

The BB1 and BB2 strains were seeded in a Petri dish with YPD agar broth (agar, yeast extract, peptone, glucose, at the concentrations of $15,10,20$ and $20 \mathrm{~g} / \mathrm{L}$, respectively). The broth was autoclaved at $121^{\circ} \mathrm{C}$ for 20 minutes and then cooled before being plaqued with the strains $P$. kudriavzevii BB1 and BB2 (Gonçalves et al., 2016), and kept for $48 \mathrm{~h}$ at $30{ }^{\circ} \mathrm{C}$.

One colony from each plate was removed and inoculated in Erlenmeyers flasks with a capacity of $250 \mathrm{~mL}$ containing the YPD broth and then agitated in shakers for $48 \mathrm{~h}$ at $25{ }^{\circ} \mathrm{C}$ and 120rpm. After sufficient yeast mass was obtained for co-inoculation in beer with composition 1:1 (P. kudriavzevii: S. cerevisiae), the cell suspension was centrifuged at room temperature, at $1200 \mathrm{rpm}$, and the supernatant was discarded, leaving only the decanted hydrated yeast, which was kept refrigerated at $5^{\circ} \mathrm{C}$ until use.

A suspension of $0.75 \mathrm{~g} / \mathrm{L}$ of the commercial strain of $S$. cerevisiae, Nottingham ${ }^{\circledR}$ (Lallemand) of high performance was prepared so that yeast could be used to inoculate the wort according to the mentioned proportion. This yeast yields a neutral combination of aromas and flavors (Chr. Hansen A / S, 2013 - modified). 


\subsection{Wort Production}

The wort was produced in aluminum containers adapted with a tap and bagasse filter, heated in a high pressure industrial stove in the Applied Biotechnology Laboratory, located in the Multidisciplinary Building at Unit II in UFGD. At the end, approximately $40 \mathrm{~L}$ of wort were produced and divided into three identical fermenters.

For the wort production, $10 \mathrm{~kg}$ of Pilsen Agrária ${ }^{\circledR}$ malt and $10 \mathrm{~g}$ of magnum hops with $12 \% \alpha$-acid were used, provided by Candando Brau, representatives of Agrária Maltes ${ }^{\circledR}$ in the Midwest, generating a beer with 7 IBU (International Bitterness Unit) as carried out by Van Rijswijck et al. (2017) with adaptations.

The malt was ground in a two-roll mill, and was added to $26 \mathrm{~L}$ of water at $54{ }^{\circ} \mathrm{C}(\mathrm{pH} 6.40)$, with no mineral correction. After the malt was added, the temperature decreased to $50{ }^{\circ} \mathrm{C}$, at which it was maintained for 15 minutes, featuring the first temperature ramp. At the end of this time interval, the temperature was increased at a rate of $1{ }^{\circ} \mathrm{C} / \mathrm{min}$ to $64{ }^{\circ} \mathrm{C}$ and kept for 60 minutes, featuring the second temperature ramp.

The Iodine Test with $2 \%$ tincture was carried out to verify the total conversion of starch to sugars. Then the mash out ramp - or enzymatic inactivation - was started, raising the temperature to $76^{\circ} \mathrm{C}$, maintained for 10 minutes, without agitation.

The clarification step, which consists of separating the bagasse (solid) from the liquid wort, was accomplished by recirculating approximately $20 \mathrm{~L}$ of wort until it was visually clearer. The clarified wort was taken to a boiling step, and the bagasse was washed with $38 \mathrm{~L}$ of water at $75{ }^{\circ} \mathrm{C}$, recirculated to obtain a clear wort.

The hops was added to the wort and the boiling started for 60 minutes. After this period, the whirpool was performeds, so that all the coagulated solids and proteins could accumulate on the bottom. A 10 minutes waiting time was necessary to allow the large particles to settle on the bottom of the container before cooling.

The wort was cooled using a 30-plates heat exchanger, being transferred from a height of approximately one meter so that it incorporated oxygen during the fall and was divided into three fermenting containers.

After boiling and cooling the wort, the yeasts were inoculated. The Control received only the commercial yeast $S$. cerevisiae Nottingham ${ }^{\circledR}$ (Lallemand) of high performance, whose aromatic fermentation profile of fermentation is neutral, which allows the evaluation of the characteristics of the other yeasts under study, without interference, as performed by Rijswijck et al. (2017), Chr. Hansen A / S (2013), Liu and Quek (2016) and Garcia (2017).

The treatments Pk.BB1 and Pk. BB2 were inoculated with the strains under study in a 1:1 ratio, that is, equal amounts of commercial yeast and Pichia kudriavzevii BB1 and BB2, as performed by Rijswijck et al. (2017).

The treatment Pk. BB1 initially received the BB1 strain while the Pk. BB2 treatment received only the BB2 strain. After three consecutive days, when these lots showed no further reduction of the original density value, they were inoculated with the yeast Nottighan (Lallemand), to finish the fermentation for another 5 days, necessary to reduce the amount of residual sugar.

The experiments were carried out in triplicate and the whole fermentation process was carried out in triplicate at 20 ${ }^{\circ} \mathrm{C}$, checked daily with the following tests: temperature measurement, determination of the sugar content $\left({ }^{\circ}\right.$ brix/original density), and $\mathrm{pH}$ value measurement.

After fermentation, maturation was done at $10{ }^{\circ} \mathrm{C}$ for ten days, and the cold crash was conducted for two days at $0{ }^{\circ} \mathrm{C}$. The beer was bottled with $6 \mathrm{~g} / \mathrm{L}$ of sugar to generate carbonation, being stored at $20^{\circ} \mathrm{C}$, for approximately 15 days.

\subsection{Physico-Chemical Analysis}

The physico-chemical analyzes carried out during the craft beer production process and on the products were the following: $\mathrm{pH}$ value, original gravity, final gravity, soluble solids ( $\left.{ }^{\circ} \mathrm{Brix}\right)$, alcohol content, attenuation and headspace analysis 
in solid phase by micro extraction coupled with gas chromatography (HS - SPME - GC).

The $\mathrm{pH}$ values were measured using a $\mathrm{pH}$ meter (Hanna, HI5521), the original gravity (OG) and final gravity (FG) in a specific gravity densimeter (Incoterm 5593), and the total amount of soluble solids ( ${ }^{\circ}$ Brix) was measured using of a portable analog refractometer (Asko, RHB0-90), in the first 10 days of fermentation as performed by Liu and Quek (2016) and Garcia (2017).

The alcohol content was calculated using Equation 1 (Papazian, 2014).

$$
A b v(\%)=(O G-F G) * 131,25 \quad \text { Equation } 1
$$

Where:

ABV: Alcohol Content

OG: Original Gravity

FG: Final Gravity

The apparent atteunation is the measurement of the fermentation extent, that is, the conversion of sugar in alcohol and $\mathrm{CO}_{2}$ (Palmer, 2017).

The apparent attenuation can be calculated according to the Equation 2.

$$
\% \text { Attenuation }=(O F-F G) /(O G-1) \times 100 \quad \text { Equation } 2
$$

Also according to Palmer (2017), the apparent attenuation can be considered low (65 to $70 \%)$, medium (71 to $75 \%$ ) or high (above 76\%).

\subsection{Gas Chromatography}

In the final products, the analysis of VOC's (volatile organic compounds) was carried out in partnership with the laboratory of the LC-GC Separations Group, from the Chemistry Institute of the State University of Campinas, in Campinas, São Paulo, Brazil.

The treatments (control, Pk. BB1 and Pk. BB2) in triplicate went through two stages of preparation. They were fisttly degassed. For that, $5 \mathrm{~g}$ of each sample were weighed in $20 \mathrm{~mL}$ flasks already containing $5 \mathrm{~mL}$ of saline solution $(\mathrm{NaCl} 30 \%$ $\mathrm{w} / \mathrm{w})$. The flasks were sealed with metal caps with septa PTFE- PDMS and the samples were degassed by freezing in a freezer $\left(-2{ }^{\circ} \mathrm{C}\right)$. After freezing, the septum of the flask was punctured with a needle to release carbon dioxide $\left(\mathrm{CO}_{2}\right)$ from the sample.

The second stage consisted of the extraction of VOC's, which used an automatic sampler (TriPlus RSH) from the gas chromatograph. The extraction was performed through solid phase microextraction (SPME) using triple fiber 50/30 mm DVD/CAR/ PDMS from Supelco. The fiber was conditioned daily before the beginning of the analyses following the manufacturer's recommendation $\left(30 \mathrm{~min}\right.$ at $270{ }^{\circ} \mathrm{C}$ ). The extraction time was 50 minutes at $45^{\circ} \mathrm{C}$, with a pre-equilibrium time of ten minutes. The flask agitation was adjusted to remain on for ten seconds and off for one second, followed by the fiber desorption time in the chromatograph injector for 5 minutes (Silva et al., 2008; Pizarro et al., 2010; Martins et al., 2015).

The gas chromatograph (TRACE 1300 by Thermo) coupled with a single quadrupole ISQ mass spectrometer, also from Thermo (Thermo Fisher Scientific - Waltham, MA, USA).

The injector operated at $260{ }^{\circ} \mathrm{C}$ in splitless mode with a 1 minute splitless time. After 1 minute, a $150 \mathrm{~mL} / \mathrm{min}$ splitflow was applied with a $0.9 \mathrm{~mL} / \mathrm{min}$ carrier gas flow (constant flow). The oven was configured to perform temperature 
ramps, starting at $45^{\circ} \mathrm{C} / 3 \mathrm{~min}$, then the temperature was raised to $220{ }^{\circ} \mathrm{C}$ at $4{ }^{\circ} \mathrm{C} / \mathrm{min}$, and finally, there was a final ramp of $220{ }^{\circ} \mathrm{C}$ for 10 minutes. A set of two columns was used, the first being a MEGA-5HT $30 \mathrm{~m} \times 0.25 \mathrm{~mm}$-id (0.25 $\mu \mathrm{m}$; $250 \beta /$ MEGA srl - Legnano, MI, Italy), and the second column an HP-50 + $5 \mathrm{~m} \times 0.25 \mathrm{~mm}$-id $(0.25 \mu \mathrm{m} ; \beta$ of 250$)$ from Agilent (Agilent Technologies - Santa Clara, CA, USA).

An INSIGHT interface (SepSolve Analytical - Peterborough, UK) was used to perform differential flow modulation using reverse flow. The modulation period was 2.5 seconds with a $250 \mathrm{~ms}$ re-injection pulse. A $50 \mathrm{~mL}$ sampling loop was used to modulate the GC $\times$ GC. Helium was used as auxiliary gas and carrier gas at constant flows of $12.85 \mathrm{~mL} / \mathrm{min}$ and $0.9 \mathrm{~mL} / \mathrm{min}$, respectively. ChromeSpace (SepSolve Analytical) was used to synchronize and control the INSIGHT modulator. The control of the chromatograph and mass spectrometer as well as the acquisition of the data was performed using the Xcalibur software (Thermo Scientific - Waltham, MA, USA) (Silva et al., 2008; Pizarro et al., 2010; Martins et al., 2015).

The mass spectrometer was configured to maintain the transfer line temperature at $250{ }^{\circ} \mathrm{C}$ and the ion source at 275 ${ }^{\circ} \mathrm{C}$. To avoid ethanol peaks that saturate the detector, a solvent cut was made for up to 4 minutes, with a sweep range of $40-$ $350 \mathrm{~m} / \mathrm{za}$ at 42 scans/s (Silva et al., 2008; Pizarro et al., 2010; Martins et al., 2015).

The volatile compounds were identified qualitatively with the derivatization of the area of each peak, representing a volatile organic compound. The Control, and the Pk. BB1 and Pk. BB2 treatments were analyzed in triplicate and two methods of multivariate chemometric analysis were used to verify a proven variation between the control, the Pk. BB1 and the Pk. BB2. With the results of this analysis, a research was made in specific databases such as The Good Scents Company (2019) and Perfurmer \& Flavorist (2018), in which the associations of the molecules with the perceived aromas could be found.

In the finished beer, a quantitative analysis of metabolites (ethanol, methanol, isoamyl alcohol and acetic acid) by gas chromatography and spectrometry was also carried out at the Instrumental Analysis Laboratory - Center for Studies in Natural Resources, UEMS. The following solvents, all of analytical grade, were used: anhydrous ethyl acetate solvents (99.8\%), ethanol standard (99.5\%), methanol standard (99.5\%), acetic acid standard (99.8\%), isoamyl alcohol standard (99.5\%), and the solutions prepared using ultrapure water.

The samples were prepared using the method described by Pinu and Villas-boas (2017) to determine the concentrations of methanol, ethanol, acetic acid and isoamyl alcohol.

Samples of $500 \mu \mathrm{L}$ of finished beer from the control treatment, Pk. BB1 and Pk. BB2 were mixed with approximately 250 mg of anhydrous sodium chloride salt until saturation, followed by intense mixing using a vortex mixer for $15-20$ s. Then, $500 \mu \mathrm{L}$ of ethyl acetate were added to the mixture and mixed for one min using a vortex mixer. The samples were then centrifuged for two min at $2000 \times \mathrm{g}$ to separate the aqueous and non-aqueous phases. The procedure was used to prepare the standards in concentration from $1 \times 10^{2}$ to $8 \times 10^{4} \mathrm{mg} / \mathrm{L}$ for methanol, 1 to $3.5 \times 10^{5} \mathrm{mg} / \mathrm{L}$ for ethanol, 2 to $5 \times 10^{4} \mathrm{mg} / \mathrm{L}$ for isoamyl alcohol and acetic acid (Pinu \& Villas-Boas, 2017).

Approximately $200 \mu \mathrm{L}$ of the upper non-aqueous phase was used for gas chromatography analysis in mass spectrometry (GC-MS). The ethyl acetate extracts were analyzed using the method described by Pinu and Villas-Boas (2017). The samples were analyzed using a gas chromatograph (GC-2010 Plus, Shimadzu, Kyoto, Japan) coupled to a mass spectrometer (GC-MS Ultra 2010, Shimadzu, Kyoto, Japan) using fused silica capillary aDB-5 (J and W, Folsom, California, USA) with $5 \%$ phenyl dimethylpolysiloxane in capillary fused silica (30m long x $0.25 \mathrm{~mm}$ inner diameter $\mathrm{x} 0.25 \mathrm{~mm}$ film thickness) (Pinu \& Villas-Boas, 2017).

A microliter of sample was injected into the GC in split mode, in the proportion of 100: 1, under constant flow of 48.851 $\mathrm{mL} / \mathrm{min}$ in the column - ionization by electronic impact (EI) at $70 \mathrm{eV}$. The injection temperature was maintained at $180{ }^{\circ} \mathrm{C}$. The $\mathrm{GC}$ oven temperature was initially maintained at $50{ }^{\circ} \mathrm{C}$ for $1 \mathrm{~min}$ and then increased to $200{ }^{\circ} \mathrm{C}$ at $40{ }^{\circ} \mathrm{C} / \mathrm{min}$. The total execution time for this 
method was $4.75 \mathrm{~min}$. The interface and detector temperatures were $210{ }^{\circ} \mathrm{C}$ and $150{ }^{\circ} \mathrm{C}$, respectively. The MS detector was turned off between $2.03 \mathrm{~min}$ to $2.21 \mathrm{~min}$ until the peak of acetate ethyl. The MS was operated in scan mode with a mass range from 30 to 250 a.m.u. (Pinu \& Villas-Boas, 2017).

\subsection{Sensory Analysis}

For the sensory evaluation, the CATA methodology (Check-All-That-Apply) was used. The project received from the Ethics Council of the Grande Dourados Federal University and the number of the consensus opinion is 3,244,894. To survey the descriptive terms to compose the evaluation form, the traditional test consisting of group discussion was carried out. In the present work, it was done with four tasters who were frequent consumers of craft beer and with the help of a leader who conducted the tasting.

From a previous list with general descriptors for beer and the compounds detected in the VOC's analysis, a previous form with general beer quality attributes was elaborated, involving the appearance, collar, flavor, aroma and aftertaste. From this, a small group with four analyzers was set up to pre-select the descriptors of the final sensory analysis. Thus, a list was obtained with 22 descriptive terms (Ares \& Jaeger, 2015).

The CATA methodology was carried out with 100 individuals, men and women, who voluntarily decided to participate in the experiment and, for that purpose, read the invitation letter and signed the necessary documents (Informed Consent Form), indicating their name, age, identification number, and assumed to be of legal age. They also received all necessary guidance, including clarification about the minimum risks that may be associated with sensory tests, such as allergy and alcohol consumption.

Before receiving the samples, the participants signed a free and informed consent form (IC), authorizing the use of the information and voluntarily agreeing to participate in the research, without any remuneration. Upon entering the tasting booth, they received a form, in which they filled in information about sex, age, enjoyed beer and consumed craft beer. Then they were asked to indicate which parameters described an ideal beer. Then, the three beer samples encoded with three-digit numbers were served, in a monadic, random and randomized way, and they were asked to mark which terms described the beer that were proving (Ares \& Jaeger, 2015).

At the end of the questionnaire, an acceptance test was carried out, in which a score of 9 points was presented to the taster ( 1 corresponded to "Disliked extremely" and 9 "Liked it extremely") and the taster should indicate how much they liked it or disliked the sample.

The statistical analysis of CATA was performed using the XLStat program. The frequency of use of each term was determined by counting the number of consumers who used each term, and then the Q-Cochran test was performed at the 5\% significance level.

After the analysis, a criterion stablished that, if less than $20 \%$ of the tasters did not mention one of the 22 descriptive terms, that term would be cut from the list in order to avoid interferences that would hinder the statistical analysis of the data. In the end, six terms were eliminated, leaving 16 to be analyzed (Ares \& Jaeger, 2015).

The acceptance test was also carried out using a 9-point hedonic scale (Disliked extremely, Liked extremely).

\section{Results and Discussion}

\subsection{Physico-Chemical Analysis}

The Figure 1 shows the $\mathrm{pH}$ values during fermentation in craft beer production using commercial strain Saccharomyces cerevisiae (control) and the Pichia kudriavzevii strains BB1 and BB2. 
Figure 1: $\mathrm{pH}$ values during fermentation in the craft beer production with commercial strain Saccharomyces cerevisiae (control) and Pichia kudriavzevii BB1 e BB2.

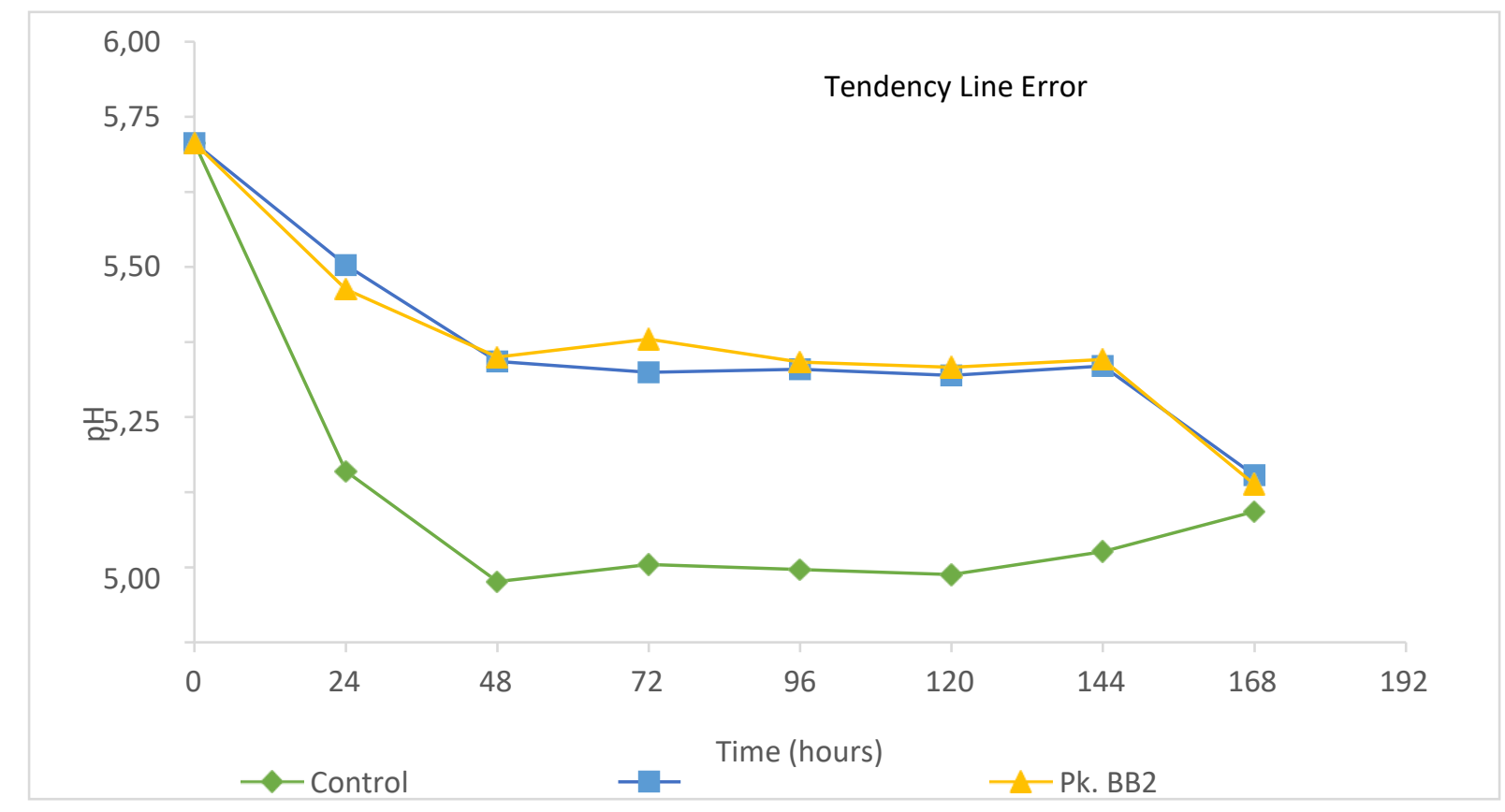

Source: Authors (2021).

The daily fermentation monitoring revealed a different behavior regarding the $\mathrm{pH}$ lowering profile of $P$. kudriavzevii (treatments BB1 and BB2) in relation to commercial yeast (control), as can be seen in Figure 1.

The control showed a considerable reduction in $\mathrm{pH}$ during the first $48 \mathrm{~h}$ of fermentation, while, in the treatments with P. kudriavzevii BB1 and BB2, this drop was much less significant.

The statistical analysis by the Tukey test at the level of $5 \%$ of significance did not reveal a significant difference (p> $0.05)$ between treatments BB1 and BB2, but there was a significant difference $(\mathrm{p} \leq 0.05)$ in relation to the control.

Monaco et al. (2014) carried out a study with yeasts of the genus P. kudriavzevii from Patagonian for the production of wines and verified a deacidification of the product due to yeast degrading malic acid, increasing the $\mathrm{pH}$ of the drink, which may cause a similar reaction in barley wort. The $\mathrm{pH}$ is an important parameter because it generates a sensation of freshness on the taste, so the use of this yeast in co-fermentation with other yeast can improve the sensory characteristics of beers that intend to have freshness as a characteristic, such as the beer under study.

Three identical batches were produced, characterizing a repetition and the average of the values of each parameter for each batch was taken to obtain the values seen in Table 1. 
Table 1. Values of wort and beer $\mathrm{pH}$, OG (original gravity), FG (final gravity), \%ABV (alcohol per volume), and \% attenuation of wort and beer.

\begin{tabular}{|c|c|c|c|}
\hline Parameters & Control & Pk. BB1 & Pk. BB2 \\
\hline$\overline{\mathrm{pH} \text { wort }}$ & $5,66^{\mathrm{a}} \pm 0,11$ & $5,66^{\mathrm{a}} \pm 0,11$ & $5,66^{\mathrm{a}} \pm 0,11$ \\
\hline OG & $1,045^{\mathrm{a}} \pm 0,004$ & $1,045^{\mathrm{a}} \pm 0,004$ & $1,045^{\mathrm{a}} \pm 0,004$ \\
\hline FG & $1,007^{\mathrm{a}} \pm 0,001$ & $1,006^{\mathrm{a}} \pm 0,001$ & $1,008^{\mathrm{a}} \pm 0,001$ \\
\hline $\mathrm{pH}$ beer & $4,56^{\mathrm{a}} \pm 0,02$ & $4,36^{\mathrm{a}} \pm 0,07$ & $4,40^{\mathrm{a}} \pm 0,10$ \\
\hline $\mathrm{ABV}(\%)$ & $4,98^{\mathrm{a}} \pm 0,35$ & $5,07^{\mathrm{a}} \pm 0,42$ & $4,85^{\mathrm{a}} \pm 0,46$ \\
\hline Attenuation (\%) & $83,3^{\mathrm{a}} \pm 1,1$ & $85,0^{\mathrm{a}} \pm 2,0$ & $81,0^{b} \pm 1,4$ \\
\hline Methanol (mg/L) & $0,33^{\mathrm{a}} \pm 0,01$ & $0,31^{b} \pm 0,01$ & $0,33^{\mathrm{a}} \pm 0,01$ \\
\hline Ethanol $(\mathrm{mg} / \mathrm{L})$ & $50734 \pm 53$ & $41061 \pm 17810$ & $40810 \pm 8792$ \\
\hline Acetic Acid (mg/L) & $2,45^{\mathrm{a}} \pm 0,02$ & $2,30^{b} \pm 0,02$ & $2,37^{\mathrm{c}} \pm 0,01$ \\
\hline Isoamylic Alcohol (mg/L) & $0,94^{\mathrm{a}} \pm 0,01$ & $0,91^{b} \pm 0,00$ & $0,95^{\mathrm{a}} \pm 0,02$ \\
\hline
\end{tabular}

Different letters in the same line indicate significant differences according to Tukey Test at $5 \%$ significance. OG: original gravity, FG: final gravity; ABV (\%): alcohol content. Source: Authors (2021).

\subsection{1 pH}

The Table 1 shows that the $\mathrm{pH}$ of the wort for the Control, BB1 and BB2 treatments was 5.66 and that there was no significant difference $(\mathrm{p}>0.05)$ in these parameters between the treatments. For Kunze (2004), the ideal pH for the coagulation of proteins from the hot break (sedimentation before cooling the wort) is 5.2 and it can be seen in Table 1 that the final $\mathrm{pH}$ of the wort -5.66 - was higher than the ideal for the fermentation stage for the three treatments.

The worts of the three treatments may have presented a $\mathrm{pH}$ above the considered ideal, due to the small amount of hops added to the beer, as the objective was to produce a slightly bitter beer, with approximately 7 IBU. The pH decreases when a larger amount of hops is added, as it contains acidic components (iso- $\alpha$-acids), which, with heat, create complexes responsible for the bitterness characteristic of the beer (Briggs et al., 2004; Venturini \& Cereda, 2001).

As for the final $\mathrm{pH}$ values, according to Table 1, values of 4.56, 4.36 and 4.40 were obtained for the Control, BB1 and BB2 treatments, respectively. For Kunze (2004), finished beers should have their optimum pH between 4.3 to 4.6 (with an excellent range between 4.2 to 4.3 ), which characterizes that the values obtained in this experiment are within the normal range.

In their study with non-Saccharomyces yeasts, Garcia (2017) found that the wort of Stout, Weiss and Dunkel-style beers had pH's of 5.10, 5.47 and 5.15, respectively, whereas Brunelli et al. (2014), found a pH of 5.74 of barley malt wort with different concentrations of honey $(0,20$ and 40\%), resulting in a beer with a final $\mathrm{pH}$ within the parameters considered normal, as well as the one obtained in this study. These studies corroborate that despite the wort having a pH above the ideal, the yeasts were able to normally excrete organic acids resulting from the metabolism itself in addition to absorb basic amino acids (Coote $\&$ Kirsop, 1976) which resulted in the $\mathrm{pH}$ of the final beer within the range of 4.0 and 4.4 considered ideal by Kaneda et al. (1997) and 4.3 and 4.6 by Kunze (2004).

\subsubsection{Original gravity and final gravity}

As can be seen in Table 1, there was no significant difference ( $p>0.05)$ regarding the original gravity (OG) between treatments, with a value of 1.045 . For this study, the beer formulations were designed to have original gravity in the range of 1.040 to 1.050 , and to obtain at the end, alcohol content between 4.5 and $5.5 \%$, similar to the mainstream beers found in the markets and that a large part of the judges are used to consuming, avoiding rejection for this specific reason, a criterion similar to that used by Garcia (2017). 
There was also no significant difference in the final gravity values ( $\mathrm{p}>0.05)$. The values of $1.007,1.006$ and 1.008 were obtained for the BB1, the BB2 and the control, respectively. These values indicate that a "dry beer", that is, with a low concentration of residual sugar, was obtained in the end.

\subsection{3 alcohol content and attenuation}

There was no significant difference for the parameter alcohol content (ABV\%) ( $>$ > 0.05), as seen in Table 1. The treatment Pk. BB2 presented 4.85\% alcohol, while Control and Pk. BB1, presented a slightly higher alcohol content, 4.98\% and $5.07 \%$, respectively. This small difference can be explained by the fact the lower attenuation observed in Pk. BB2, which differs statistically $(\mathrm{p} \leq 0.05)$ from the control and Pk. BB1 according to the Tukey test at 5\% significance. While the Control showed an attenuation of $83.3 \%$ and the $\mathrm{Pk}$. BB1 an attenuation of $85.0 \%, \mathrm{Pk}$. BB2 showed an attenuation of $81 \%$.

The attenuation directly implies the lower alcohol content of the final product. The greater the attenuation, the more alcoholic the beer and a drier (less residual sugar) sensation the beer will leave on the taste (Garcia, 2017). The lower attenuation shown by Pk. BB2 compared to the Control and the Pk. BB1 can be explained by the production of enzymes, toxins (killer toxins) or fermentation by-products produced by $\mathrm{Pk}$. BB2 and not produced by Pk. BB1. These metabolits potentially decrease the activity of the commercial yeast, preventing it from transforming all the sugar present in the wort into alcohol and carbon dioxide $\left(\mathrm{CO}_{2}\right)$, as found by Steensels and Vertstrepen (2014) and Ciani and Comitini (2010). Moreover, the lower attenuation seen by $\mathrm{Pk}$. BB2 can be attributed to a lower capacity to assimilate more complex sugars such as maltose, maltotriose and dextrins, which are the main sugars in beer wort (Kurtzman et al., 2011).

\subsubsection{Methanol and Ethanol Concentrations}

There was a statistically siginificant difference $(\mathrm{p} \leq 0.05)$ for the methanol concentration between the Control and the Pk. BB2 $(0.33 \mathrm{mg} / \mathrm{L})$ and the Pk. BB1 $(0.31 \mathrm{mg} / \mathrm{L})$. Methanol is a public health concern because it can cause problems in the optic nerve and in the central nervous system (Paine \& Dayan, 2001). Countless fermented and fermented alcoholic beverages have small concentrations of methanol, and Paine and Dayan (2001) states that the consumption of methanol in maximum concentrations of $5 \mathrm{mg} / \mathrm{dl}$ of blood is safe, meaning that for an $70 \mathrm{~kg}$ adult, an intake of $1950 \mathrm{mg}$ of methanol is considered "safe" (corresponding to $2 \%[\mathrm{v} / \mathrm{v}])$.

The highest natural concentration of methanol in alcoholic beverages reported was $18 \mathrm{~g} / \mathrm{L}$ (equivalent to $0.72 \%$ [v/v]) in fruit liqueurs, which is unlikely to cause poisoning by this substance in most of individuals. Therefore, it can be said that the treatments under study showed safe concentrations of methanol (Paine \& Dayan, 2001).

The concentration of ethanol can be seen in Table 1. This parameter varies according to the concentration and types of sugars in the wort, yeast species, fermentation temperature, among other parameters (Kunze, 2004). There was no statistical difference $(\mathrm{p}>0.05)$ for this parameter between the treatments in the study.

Ethanol is the main alcohol produced by the yeast Saccharomyces cerevisiae and it contributes to the perception of different tastes in beer such as sweetness, bitterness and acidity, and it also influences the release of aromas during beer consumption (Ramsey et al., 2018).

\subsubsection{Acetic Acid and Isoamyl Alcohol Concentration}

Acetic acid, as well as other organic acids (malic, lactic, pyruvic) are produced as a by-product of yeast metabolism. The Control produced $2.45 \mathrm{mg} / \mathrm{L}$, while $\mathrm{Pk}$. BB1 produced $2.30 \mathrm{mg} / \mathrm{L}$ and $\mathrm{Pk}$. BB2 $2.37 \mathrm{mg} / \mathrm{L}$, all treatments differing statistically from each other $(\mathrm{p} \leq 0.05)$. Klopper et al. (1986) studied the production of organic acids and glycerol in different types of beer and found that the "pilsener" style shows concentrations of acetic acid between 9 and $139 \mathrm{mg} / \mathrm{L}$, whereas in the 
ale-type beers, it ranges between 56 and $136 \mathrm{mg} / \mathrm{L}$.

The investigation of the presence of isoamyl alcohol in the treatments showed that Control and Pk. BB2 differed statistically ( $\mathrm{p} \leq 0.05)$ from the Pk treatment. BB1. In his study of beer production with Torulospora delbrueckii, Canonico et al. (2016) showed that the treatment produced exclusively with this strain produced a beer with $3.82 \mathrm{mg} / \mathrm{L}$ of isoamyl alcohol, and the treatment with the strain of S. cerevisiae US -05 showed greater concentration when compared to the non-Saccharomyces strain, as found in this study with the Pk BB1.

\subsubsection{Bio-Aromatic Compounds}

The analysis of microextraction in solid phase was performed to detect which aromatic compounds were present in the treatments and to verify if the yeasts Pk. BB1 and BB2 were able to bio-aromatize the beers. To assess the differences between treatments, a two-step statistical analysis was performed.

First, a PCA analysis (Principal Component Analysis) was performed with the three treatments (Control, BB1 and BB2), in which it was possible to detect 28 aromatic compounds that differentiated the control from the BB1 / BB2 group, being 20 esters, 2 alcohols, 5 carboxylic acids, and 1 hydrocarbon, as shown in Table 2.

With the result obtained by the first PCA analysis, it was only possible to differentiate the Control from the BB 'group, failing to find any main compound to differentiate Pk. BB1 from Pk. BB2.

A second statistical analysis was necessary; using the Fisher methodology, to identify compounds had proven variation between BB1 and BB2 treatments (Table 3). It was found that 14 compounds differentiated BB1 from BB2, with 10 esters, 1 alcohol, 1 carboxylic acid and 2 hydrocarbons. 
Table 2. Volatile Compounds found in the treatments of craft beers using the commercial yeast Saccharomyces and the BB1 \& BB2 strains of the Pichia genus, detection threshold, charateristics and comparison of intensity between the control and the Pichia (BB1 \& BB2).

\begin{tabular}{|c|c|c|c|c|c|}
\hline Class & Volatile Compounds (IUPAC) & Common Name & $\begin{array}{c}\text { Detection } \\
\text { Threshold } \\
(\text { ppm })\end{array}$ & Characteristics & Intensity in the Beer \\
\hline \multirow{20}{*}{ Esters } & 1-Buthanol, 3-methil-, acetate & Isoamyl acetate & 30 & sweet, fruity, banana, solvent & Control > BB1 \& BB2 \\
\hline & Acetic acid, 2-fenylethyl ester & Phenylethyl acetate & 25 & floral, rose, honey, tropical fruits & Control > BB1 \& BB2 \\
\hline & Acetic acid, heptyl ester & Heptyl acetate & 7,5 & ripe fruit, pear, apricot, wood & Control $>\mathrm{BB} 1 \& \mathrm{BB} 2$ \\
\hline & Acetic acid, hexyl ester & Hexyl acetate & 15 & apple, sweet, banana, nut & Control > BB1 \& BB2 \\
\hline & Acetic acid octyl ester & Octyl acetate & 10 & earthy, mushroom, herbal & Control > BB1 \& BB2 \\
\hline & Butanoic Ácid, 3-methylbuthyl ester & Isoamyl butirate & - & apricot, pear, banana & Only in Control \\
\hline & Butanoic acid, ethyl ester & Ethyl butirate & 2 & fruity, ananas, brandy & BB1 \& BB2 > Control \\
\hline & Decanoic acid, ethyl ester & Ethyl decanoate & 1520 & sweet, apple & Control $>\mathrm{BB} 1 \& \mathrm{BB} 2$ \\
\hline & Dodecanoic acid, ethyl ester & Ethyl dodecanoate & 10 & floral, soap, clean & Control $>\mathrm{BB} 1 \& \mathrm{BB} 2$ \\
\hline & Ethyl 9-decenoate & Ethyl 9-decenoate & - & fruity, grassy & Control $>\mathrm{BB} 1 \& \mathrm{BB} 2$ \\
\hline & Heptanoic acid, ethyl ester & Ethyl heptanoate & 20 & ananas, winy & Control $>\mathrm{BB} 1 \& \mathrm{BB} 2$ \\
\hline & Isobuthyl acetate & Isobuthyl acetate & - & banana & Control $>\mathrm{BB} 1 \& \mathrm{BB} 2$ \\
\hline & Isopenthyl hexanoate & Isoamyl hexanoate & - & banana, apple, ananas & Only in Control \\
\hline & n-Capric acid, isobuthyl acid ester & Isobuthyl decanoate & - & fermentation, apricot, brandy & Only in Control \\
\hline & Caprilic acid, isobuthil ester & Isobuthyl octanoate & 10 & fruity. floral & Contro $>$ BB1 \& BB2 \\
\hline & Nonanoic acid, Ethyl ester & Ethyl nonanoate & 5 & Rose, wine & Control > BB1 \& BB2 \\
\hline & Octanoic acid, 3-methylbuthyl ester & Isoamyl octanoate & - & sweet, ananas, coconut & Control $>\mathrm{BB} 1 \& \mathrm{BB} 2$ \\
\hline & Octanoic acid, ethyl ester & Ethyl octanoate & 5 & winy, apricot, banana, pear & Contro > BB1 \& BB2 \\
\hline & $\begin{array}{c}\text { Pentadecanoic acid, 3-methylbuthyl } \\
\text { ester }\end{array}$ & Isoamyl decanoate & - & banana, fruta sweet, brandy & Only in Control \\
\hline & Undecanoic acid, ethyl ester & Ethyl endecanoate & 25 & soap, coconut, brandy & Control > BB1 \& BB2 \\
\hline \multirow{3}{*}{ Alcohols } & Phenylethylic alcohol & Phenyl-ethyl alcohol & - & floral, rose, rosa seca & Control $>\mathrm{BB} 1 \& \mathrm{BB} 2$ \\
\hline & 1-Octanol & Octanol & 5 & orange, rose, mushroom & $\mathrm{BB} 1 \& \mathrm{BB} 2>$ Control \\
\hline & 1-Pentanol & Amylic Alcohol & 50 & bread, yeast, solvent & BB $1 \&$ BB2 > Control \\
\hline \multirow{5}{*}{$\begin{array}{l}\text { Carboxilic } \\
\text { Acids }\end{array}$} & $\begin{array}{c}\text { 2-Butenoic acid, 2-methyl-, ehyl } \\
\text { ester }\end{array}$ & Ethyl tiglate & - & sweet, tutti frutti, floral, caramel & Control $>\mathrm{BB} 1 \& \mathrm{BB} 2$ \\
\hline & Hexanoic acid & Caproic acid & 10 & cheese, sweaty & Control $>\mathrm{BB} 1 \& \mathrm{BB} 2$ \\
\hline & Hexanoic acid, ethyl ester & Ethyl caproate & 7 & sweet, ananas, banana & Control $>\mathrm{BB} 1 \& \mathrm{BB} 2$ \\
\hline & n-Decanoic acid & Decanoic acid & 510 & rancid, oily, citric & Control > BB1 \& BB2 \\
\hline & Octanoic acid & Octanoic acid & 10 & oily, rancid,cheese & Control > BB1 \& BB2 \\
\hline Hydrocarbons & Styrene & Styrene & 2,5 & balsamic, floral & Control > BB1 \& BB2 \\
\hline
\end{tabular}

The association between the VOC and the aroma compounds was found in "The Good Scents Company" and in the website "Perfurmer \& Flavorist” (The Good Scents Company, 2019; Perfumer \& Flavorist, 2019). Source: Authors (2021). 
Table 3. Volatile compounds found in craft beer treatments using P. kudriavzevii BB1 and BB2, detection threshold, characteristics, and intensity comparison between the P. kudriavzevii BB1 and BB2.

\begin{tabular}{|c|c|c|c|c|c|}
\hline Class & Volatile Compounds (IUPAC) & Common Name & $\begin{array}{c}\text { Detection } \\
\text { Threshold } \\
\text { (ppm) }\end{array}$ & Characteristics & Intensity in the Beer \\
\hline \multirow{10}{*}{ Estheres } & 1-Butanol, 3-methyl-, acetate & Isoamyl acetate & 30 & $\begin{array}{c}\text { sweet, fruity, } \\
\text { banana, solvente }\end{array}$ & $\mathrm{BB} 1>\mathrm{BB} 2$ \\
\hline & Acetic acid, heptil ester & Heptyl acetate & 7.5 & $\begin{array}{l}\text { pear, apricot, } \\
\text { woody }\end{array}$ & $\mathrm{BB} 1>\mathrm{BB} 2$ \\
\hline & Acetic acid, hexil ester & Hexyl acetate & 15 & $\begin{array}{l}\text { fruity, green apple, } \\
\text { banana }\end{array}$ & $\mathrm{BB} 1>\mathrm{BB} 2$ \\
\hline & Acetic acid, octil ester & Octyl acetate & 10 & $\begin{array}{c}\text { earthy, } \\
\text { mushroom,apple }\end{array}$ & $\mathrm{BB} 1>\mathrm{BB} 2$ \\
\hline & Acetic acid, pentil ester & Amyl acetate & 30 & $\begin{array}{c}\text { ethereal, banana, } \\
\text { pear, apple }\end{array}$ & $\mathrm{BB} 2>\mathrm{BB} 1$ \\
\hline & Butanoic acid, ethyl ester & Ethyl butirate & 2 & $\begin{array}{l}\text { fruity, ananas, } \\
\text { brandy }\end{array}$ & $\mathrm{BB} 2>\mathrm{BB} 1$ \\
\hline & Decanoic acid, ethyl ester & $\begin{array}{c}\text { Ethyl } \\
\text { dodecanoate }\end{array}$ & 1520 & $\begin{array}{l}\text { sweet, fruity, } \\
\text { apple, grape }\end{array}$ & $\mathrm{BB} 1>\mathrm{BB} 2$ \\
\hline & Decanoic acid, ethyl ester & Ethyl laurate & 10 & sweet, floral, soap & $\mathrm{BB} 1>\mathrm{BB} 2$ \\
\hline & Nonanoic acid, ethyl ester & Ethyl nonate & 5 & rose, winy & $\mathrm{BB} 1>\mathrm{BB} 2$ \\
\hline & Octanoic acid, ethyl ester & $\begin{array}{c}\text { Ethyl } \\
\text { octanoate }\end{array}$ & 5 & $\begin{array}{l}\text { winy, apricot, } \\
\text { banana, pear }\end{array}$ & $\mathrm{BB} 1>\mathrm{BB} 2$ \\
\hline Alcohol & 1-heptanol & Heptyl Alcohol & - & $\begin{array}{l}\text { moss, herbal, } \\
\text { solvent }\end{array}$ & $\mathrm{BB} 2>\mathrm{BB} 1$ \\
\hline Carboxilic Acid & Ácido benzacético, etil esther & Acetic acid & - & $\begin{array}{l}\text { ethereal, sweet } \\
\text { fruit, vegetal }\end{array}$ & $\mathrm{BB} 1>\mathrm{BB} 2$ \\
\hline \multirow{2}{*}{ Hydrocarbons } & Pentene, 2,2,4-trimethyl- & Isoctane & & - & $\mathrm{BB} 2>\mathrm{BB} 1$ \\
\hline & styrene & Styrene & 2,5 & balsamic, spicy & $\mathrm{BB} 2>\mathrm{BB} 1$ \\
\hline
\end{tabular}

The association between the VOC and the aroma compounds was found in "The Good Scents Company" and in the website "Perfurmer \& Flavorist” (The Good Scents Company, 2019; Perfumer \& Flavorist, 2019). Source: Authors (2021).

As can be seen in Table 2, the control - produced with commercial yeast - and classified as neutral by the manufacturer, resulted in a greater amount of compounds compared to BB1 and BB2, such as isoamyl acetate, phenylethyl acetate, heptyl acetate and hexyl acetate, as well as compunds that were not present in BB1 nor BB2, such as ethyl butyrate and isoamyl hexanoate. However, these compounds were probably produced in small quantities, below the threshold of the tasters' perception.

Silva, Augusto and Poppi (2008) found the compounds 1-pentanol, 1-octanol, octanoic acid and ethyl decanoate in Brazilian commercial pilsner beers. In a similar study carried out by Riu-aumatell et al. (2014) isoamyl acetate, isoamyl butyrate, hexyl and heptyl acetate, 1-octanol, phenyl ethyl alcohol, decanoate and ethyl dodecanoate were found.

Beers, as well as other alcoholic beverages, such as wines and whiskey, are rich in esters and alcohols formed during fermentation by reactions between acetyl-Co A and higher alcohols (Riu-Aumatell et al., 2014), giving beer a profile that ressembles to fruity aromas of banana, ripe fruit, spices, orange, yeast, among others.

Higher alcohols are one of the most abundant volatile compounds in beer (Pires et al., 2014) and are direct precursors to the production of esters, contributing positively to the aroma and flavor of beer (Mander \& Liu, 2010). The production of higher alcohols occurs when yeasts absorb amino acids present in the wort, and incorporate the amino group in their own structure, leaving the keto- $\alpha$-acids as a byproduct. These acids enter irreversibly in chain reactions that will then result in the production of higher alcohols (Pires et al., 2014).

Table 2 shows that the production of higher alcohols 1-octanol and 1-pentanol was higher in the BB group than in the control. According to Table 3, the production of 1-heptanol was higher in the treatment with yeast BB2 compared to BB1. 
Observing Tables 2 and 3, the higher alcohols 1-octanol, 1-pentanol, and 1-heptanol were found. The production of these substances can be stimulated by the high rate of yeast inoculation, by the fermentation conditions or by the type of raw material. The combination of oxygen presence, high fermentation temperature and rich broth, favors the Krebs cycle, and the consequent formation of these higher alcohols in the yeast growth phase (Rossi et al., 2013).

Silva, Augusto and Poppi (2008) also found in their experiment with 'pilsen' beers that the presence of octanoic and / or caprylic acid can increase the fermentation rate, and cause the production of higher alcohols that are not desirable in large quantities in beers.

The styrene hydrocarbon was found mainly in the control, but also in the treatments of the yeasts Pk. BB2 and BB1, in this decreasing order of concentration (Table 2). This compound is produced by the enzymatic or thermal decarboxylation of cinnamic acid, present in barley malt, and is a precursor to aromatic phenolic compounds, such as 4-vinyl-guaiacol, which can be considered off-flavor for some beer styles (Rossi et al., 2013). High concentrations of this substance are undesirable and can produce sweet aromas, which refer to balsamic vinegar, or resinous aroma (Viejo et al., 2019). In the sensory analysis, no aroma was detected that referred to these flavors, which leads to believe that it was present in low concentrations.

In their study on beer production in mixed fermentation (S. cerevisiae / T. delbrueckii), Canonico et al. (2016) concluded that the use of different yeasts can change the profile of volatile organic compounds without modifying any stage in the production process or adding enzymes that act on certain malt proteins, promoting an increase in the concentration of some higher aromatic alcohols.

\subsection{Sensory Analysis Using CATA Methodology}

The Sensory analysis based on the CATA methodology was carried out with 93 participants, being 57\% women and $43 \%$ men, with an average age of 22 years. Most participants (95\%) declared that they like beer and a smaller percentage (79\%) said to drink craft beer.

The results obtained in the test performed are shown in Table 4, which shows the frequency of use for each term, as well as the statistical analysis, which determines if there is a significant difference between the treatments by the Q-Cochran Test.

Table 4. Q-Cochran test with the frequencies of use of each term describing craft beer (Control, BB1 and BB2).

\begin{tabular}{ccccc}
\hline Characteristic & p-value & Control & Pk. BB1 & P $\boldsymbol{k}$ BB2 \\
\hline Good foam formation & 0.000 & 0.516 (b) & 0.452 (b) & 0.097 (a) \\
Non-uniform foam & 0.360 & 0.301 (a) & 0.215 (a) & 0.258 (a) \\
Little collar & 0.005 & 0.473 (a) & 0.527 (ab) & 0.667 (b) \\
Ceral aroma/flavor & 0.194 & 0.462 (a) & 0.355 (a) & 0.355 (a) \\
Yeast aroma/flavor & 0.014 & 0.215 (a) & 0.398 (b) & $0.280(\mathrm{ab})$ \\
Alcoholic favor & 0.657 & 0.376 (a) & 0.366 (a) & 0.419 (a) \\
Ripe fruit aroma & 0.021 & 0.065 (a) & 0.194 (b) & 0.129 (ab) \\
Fruity aroma & 0.184 & 0.172 (a) & 0.129 (a) & 0.226 (a) \\
White wine aroma/flavor & 0.799 & 0.172 (a) & 0.172 (a) & 0.204 (a) \\
Cider aroma (fermented apple) & 0.048 & 0.108 (a) & 0.161 (a) & 0.226 (a) \\
Sight acidic flavor & 0.454 & 0.312 (a) & 0.344 (a) & 0.398 (a) \\
Slight bitter flavor & 0.541 & 0.538 (a) & 0.548 (a) & 0.473 (a) \\
Ripe fruit flavor & 0.590 & 0.129 (a) & 0.183 (a) & 0.161 (a) \\
$\quad$ Pleasant & 0.003 & 0.753 (b) & 0.538 (a) & 0.570 (a) \\
Stimulates the next sip & 0.005 & 0.624 (b) & 0.409 (a) & 0.462 (ab)
\end{tabular}

Averages with the same letter in the same line do not differ at the 5\% siginificance level according to the Cochran test. Source: Authors (2021). 
As shown in Table 4, the attributes "good foam formation", "little collar", "yeast aroma/flavor", "ripe fruit aroma", "pleasant" and "stimulates the next sip" differed significantly from each other $(\mathrm{p} \leq 0.05)$ demonstrating that in these questions, the treatments showed physical and sensory differences.

On the other hand, the parameters "non-uniform foam", "cereal aroma/flavor", "alcoholic aroma", "fruity aroma", "white wine aroma/ flavor", "cider aroma", "slight acidic taste", "slight bitter taste" and "ripe fruit flavor", did not show significant difference $(p>0.05)$ to the level of significance adopted in the test. This non-significant difference may be due to the fact that the treatments are relatively similar to each other (Ares et al., 2010).

Also according to the Q-Cocham test results in Table 4, there was a significant difference $(\mathrm{p} \leq 0.05)$ in the parameters "yeast aroma/flavor" and "ripe fruit aroma", which is in accordance with what is shown in both Tables 2 and 3, as the substance 1-Pentanol (amyl alcohol) refers to yeast aroma, bread, and, depending on the concentration, can produce solventlike notes.

As for foam, the Control treatment showed a better average in the requirement "good foam formation" (51.6\%, Table $4)$, and is statistically equal ( $p>0.05)$ to the BB1 treatment, differing from the BB2 treatment ( $p \leq 0.05)$, which is consistent with the fact that it was recognized by 66 tasters as a beer with "little collar", differing from the Control and BB1 treatments (p $\leq 0.05)$.

The foam of beer is directly related to the amount of protein derived from malt and hops. The quality of the foam is defined by Bamforth, Russell and Stewart (2008) as a combination of stability, quantity, capacity to form lace (adhesion to the glass), whiteness, creaminess and strength. It is known that yeast $P$. kudriavzevii has a robust enzymatic apparatus, which involves proteases, pectinases, xylanases, among others, which is very interesting for the production of wines, but which must be viewed sparingly for the production of beer, once that the formation and stability of the foam can be impaired, according to Mónaco, Rodríguez and Lopes (2016). It may be that the yeast Pk. BB2 synthesizes or degrades proteins responsible for foaming to produce other important compounds for its metabolism.

From Table 4 it is also possible to verify the most and least cited terms by the tasters, through the frequency analysis by the Cochan test. The term "pleasant" was the most cited descriptor in the Control treatment, while "little collar", "pleasant" and "slightly bitter taste" were the most cited for BB1 treatment while "little collar", "slightly bitter taste" and "stimulates the next sip" was the most marked in the BB2 treatment. The least mentioned terms for the Control, BB1 and BB2 treatments were "tutti frutti aroma" and "apple flavor".

The descriptor "ripe fruit aroma" differed statistically $(\mathrm{p} \leq 0.05)$ in the three treatments, and was most remarkable in treatment BB1 (marked by 19 tasters), followed by the BB2 (12 tasters) and the Control ( 6 tasters).

The substances 1-Butanol, 3-methyl-, acetate, acetic acid, hexyl esther, decanoic acid, ethyl esther, benzene-acetic acid, which refer to the fruity flavor class, are present in greater concentration in the BB1 treatment than in BB2, as shown in Table 3, supporting and explaining the results seen in Table 4.

As for the descriptor "yeast aroma/flavor", the difference was significant $(\mathrm{p} \leq 0.05)$ between the Control and BB1 treatments, while the BB2 treatment did not show significant difference $(\mathrm{p}>0.05)$ from both. The yeast aroma is an attribute that can be caused by the yeast's flocculation habit, and although the Control treatment is described by the manufacturer as a highly flocculative yeast, which sits at the bottom of the maturing tank, not altering the sensory characteristics of the beer, however, it was perceived by $21.5 \%$ of the tasters as shown in Table 4 .

It is believed that the control treatment was the most described as pleasant because it has more similar characteristics to commercial beers, commonly consumed by the tasters. The little collar descriptor, on the other hand, was quite marked in treatments containing the yeast $P$. kudriavzevii (BB1 and BB2). This may be due to the robust enzymatic apparatus from these strains, containing 
proteases (Mónaco et al., 2016) that can synthesize proteins responsible for the formation and retention of foam in beer, thus damaging the collar of treatments BB1 and BB2.

Regarding the "slight bitter taste", there was no significant difference $(p>0.05)$ between treatments, this descriptor was quite mentioned by the evaluators for all treatments - 53.8, 54.8 and $47.3 \%$ of the tasters assigned this descriptor to Control, BB1 and BB2, respectively. As most of the evaluators are consumers of mainstream beers (commercial "Pilsen" or American Light Lager style beers), even with low bitterness (IBU), this characteristic was marked by 54 evaluators in the control and the BB1 and by 47 evaluators on the BB2. Although the treatments had a low level of bitterness, the beers were characterized with the descriptor "slightly bitter taste", possibly because the tasters are not used to ingesting beers with these characteristics.

The hierarchical analysis of clusters (or classes) suggests that the tasters should be divided into two classes, according to the dendrogram in Figure 2.

Figure 2. Dendrogram of hierarchical division of Clusters or Classes.

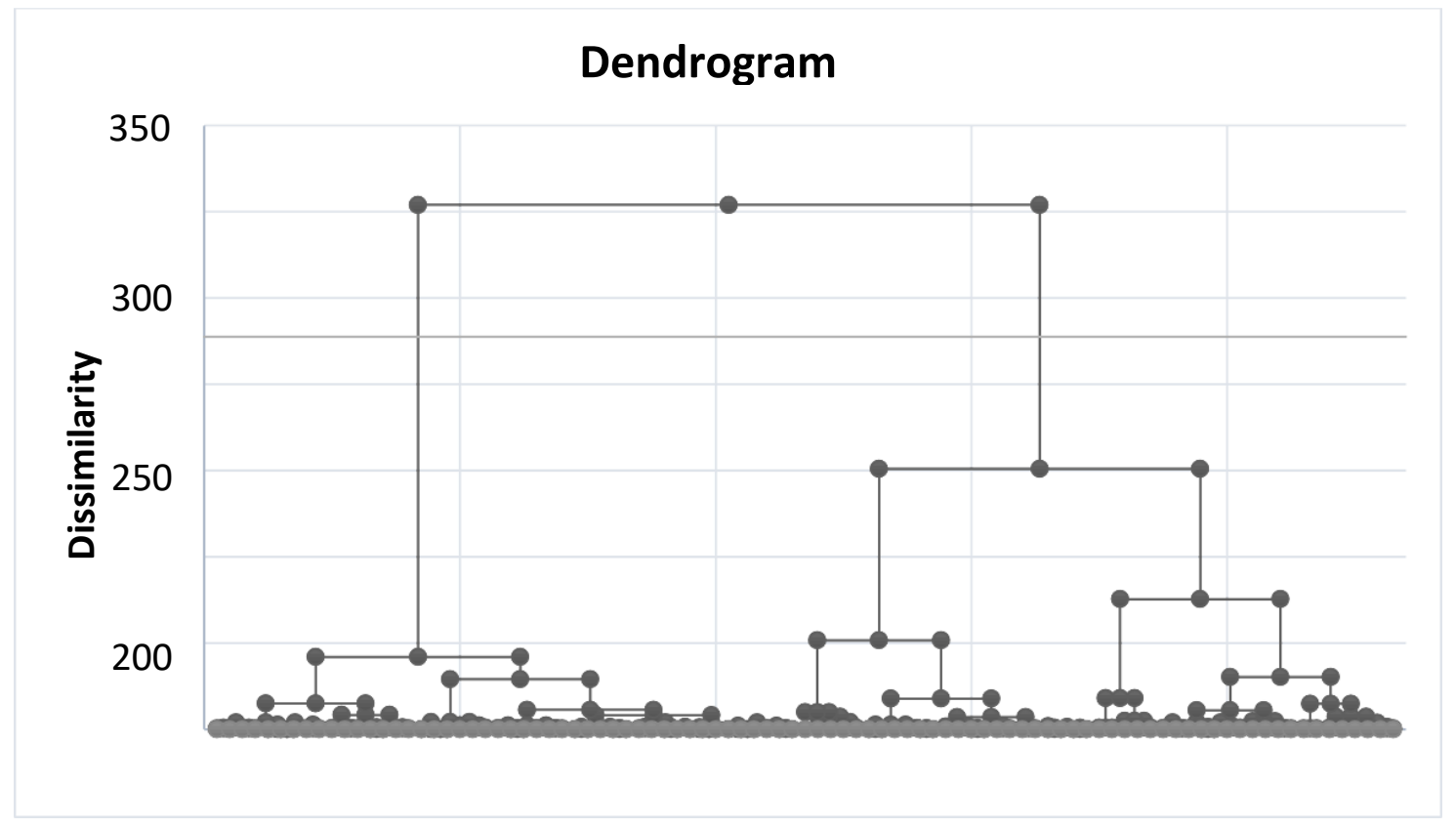

Source: Authors (2021).

Figure 2 shows a significant increase in dissimilarity from two to three clusters, which suggests that after this division number, the clusters start to become homogeneous, as suggested by Liobell et al. (2019).

Table 5 presents the analysis by clusters (classes) in which the tasters were divided into two classes, the first with 46 and the second with 47 members.

Analysing the data in Table 5, it is possible to identidy that the tasters can be divided into two main clusters, according to the score assigned to each sample of treatments of craft beers Control, Pk. BB1 and Pk. BB2. 
Table 5. Analysis by clusters (classes) in which the tasters were divided into two classes, the first with 46 and the second with 47 members.

\begin{tabular}{ccccc}
\hline Parameter & & $\begin{array}{c}\text { Global } \\
(n=93)\end{array}$ & $\begin{array}{c}\text { Cluster 1 } \\
(n=46)\end{array}$ & $\begin{array}{c}\text { Cluster 2 } \\
(n=47)\end{array}$ \\
\hline \multirow{3}{*}{ Score $(0-9)$} & Control & 7,3 & 7,5 & 7,1 \\
& $P k$. BB1 & 6,3 & 7,7 & 5,0 \\
Gender & $P k$. BB2 & 6,6 & 7,8 & 5,4 \\
& Man & 40 & 15 & 25 \\
\hline \multirow{2}{*}{ Occupation } & Woman & 53 & 31 & 22 \\
\hline \multirow{2}{*}{ Beer consumption habits } & Student & 45 & 40 & 2 \\
\hline
\end{tabular}

Source: Authors (2021).

From Table 5, it can also be seen that the 46 tasters in Cluster 1 assigned higher scores for the treatments of craft beers made with Pk. BB1 and Pk. BB2, while the 47 tasters in Cluster 2 assigned lower scores for the same treatments. In addition, 39 tasters in Cluster 1 drink craft beer, while 12 in Cluster 2 do not drink. Looking at these data, it can be assumed that the habit of consuming craft beer may be related to the acceptance of bioaromas produced by Pk. BB1 and Pk. BB2, with tasters who consume craft beer giving a higher score in the acceptance test than those who do not. Moreover, Cluster 1 has $48 \%$ more females, which may indicate that women tend to give a higher grade to beer produced with Pk strains. BB1 and BB2 when compared to men.

Figure 3 shows the final appearance of craft beers made with commercial yeast (control) and the strains studied (BB1 and $\mathrm{BB} 2)$.

Figure 3. Final aspect of the beers produced using the yeasts Saccharomyces (control) and Pichia kudriavzevii BB1 e BB2, respectively.

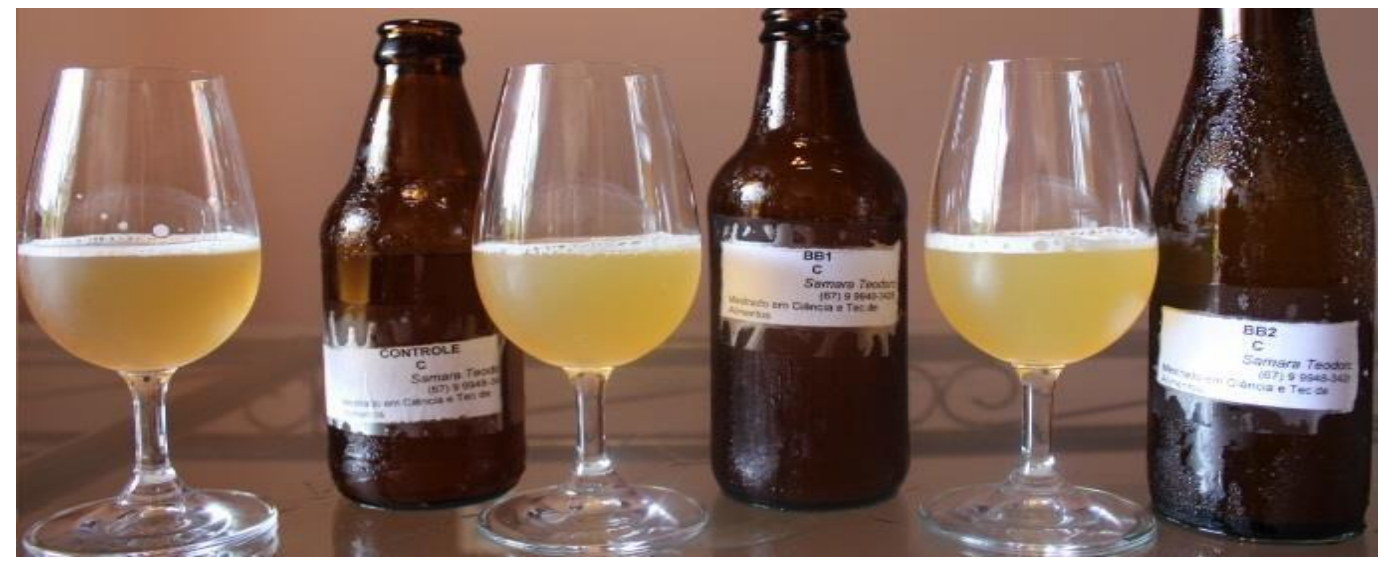

Picture: Regiane Riquena. Source: Authors (2021).

The Pk treatments BB1 and BB2 are noticeably more turbid, as seen in Figure 3, and formed a suspended material on the neck of the bottle, which probably contributed to the yeast aroma / flavor.

For Varela (2016), species such as Torulospora delbrueckii provide clarity to the beer and persistent and compact foam, unlike what was found in this experiment, in which it was perceived that the foam from the Pk treatments. BB1 and BB2 
had little persistence and were uneven, containing larger and smaller bubbles.

Figure 4 shows the Principal Component Analysis (PCA) of craft beers from Control treatments and those inoculated with $\mathrm{Pk} . \mathrm{BB} 1$ and BB2 and the profile considered as ideal by the tasters.

Figure 4. Principal Component Analysis (PCA) of craft beers from Control and those inoculated with the strains Pichia kudriavzevii $\mathrm{BB} 1$ and $\mathrm{BB} 2$ with the profile considered as ideal by the tasters.

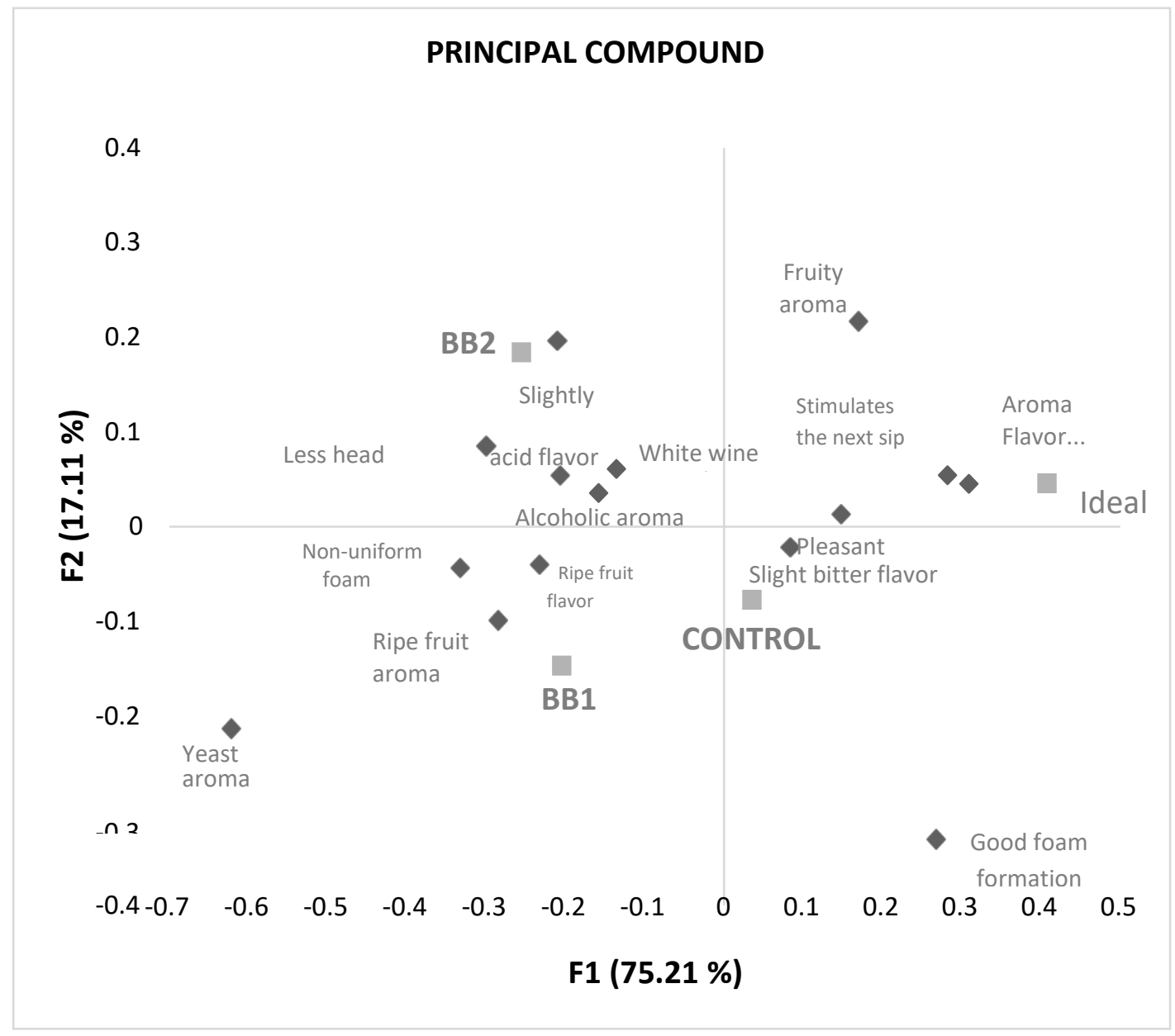

Source: Authors (2021).

The Principal Compunds Analysis suggests adjacent patterns or relationships through the distance of the points (Ares \& Jaeger, 2015). Figure 4 shows the first main component (F1), which concentrates most of the total variation found in the original data (75.21\%), and the second main component (F2) explains the rest of the variation $(17.11 \%)$, with $92.32 \%$ being the total data variation.

Through the PCA of Figure 4, it can be seen that the Control treatment presented characteristics closer to what is considered “ideal beer" by the tasters. In addition, the descriptive terms "cereal aroma / flavor", "spices aroma", "tutti frutt aroma”, "stimulates the next sip", and "pleasant", are the most pointed characteristics for a beer ideal (Figure 4). These descriptive terms were mentioned more frequently, as can be seen in Table 4, with the Control treatment being more frequent than BB1 and BB2.

Figure 4 shows that the BB1 treatment was explained by the attributes "ripe fruit aroma", "yeast flavor aroma", and "nonuniform foam", while BB2 treatment was explained by "apple flavor", " apple cider aroma", "little collar ", "non-uniform foam", "apple aroma" and "slight acidic taste". 
In the experiment carried out by Alexi et al. (2018), a quick pre-training (less than 60 minutes) with physical references (fruits, herbs, and other ingredients to practice the aromas found in beer), resulted in a positive effect in the citation of attributes, identification of tastes and complex flavors, which helped in the differentiation of treatments by the tasters, showing a potential alternative for industrial use, which can be adopted as a suggestion for similar experiments, in which treatments that are very close to each other are evaluated.

This shows that the consumer's taste is accustomed to an aromatic profile, for this style of beer, more neutral. Further studies should be employed observing the behavior of yeast in relation to different styles of beer and the use of different types and amounts of hops as performed by Chr. Hansen A / S (2013).

Through the analysis of main components of Figure 5 in which it is possible to verify which parameters are essential for a good acceptance of the treatments.

Figure 5. Principal component analysis of the acceptance characteristics of the craft beers using commercial Saccharomyces strains, and the studied Pichia kudriavzevii BB1 and BB2 strains.

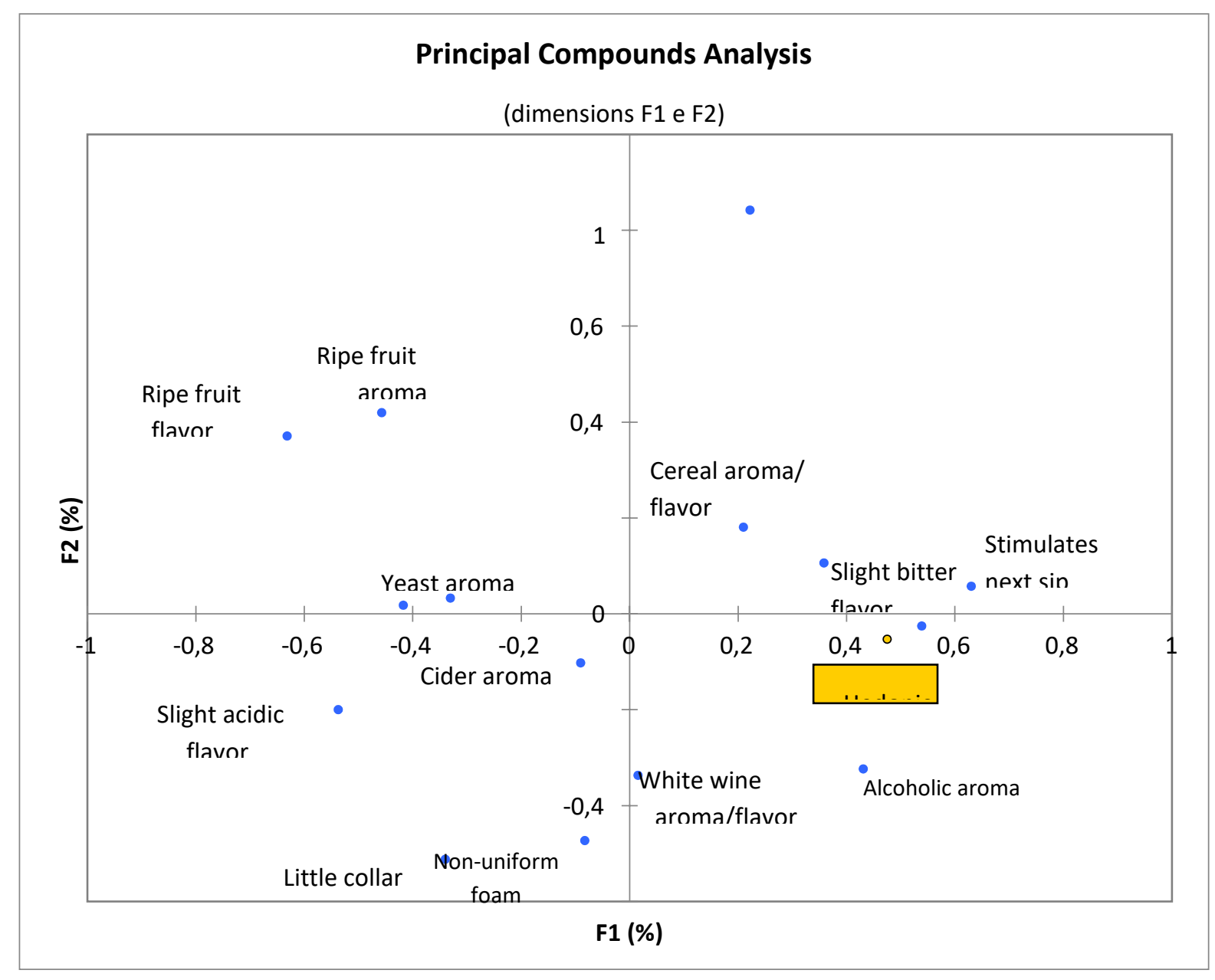

Source: Authors (2021).

Through Figure 5, it can be concluded that for the profile of tasters that participated in the study, the beers that have the characteristics "pleasant", "stimulates the next sip", "slightly bitter taste" and "cereal aroma / flavor", "white wine aroma / flavor", "alcoholic aroma" and "cider aroma" have a higher score in the hedonic test, with the parameter "pleasant" increasing the hedonic test score by 2.7 points. 
In Figure 6, the comparison between real treatments and a hypothetical ideal product can be seen in the graph.

Figure 6. Citation rates difference between treatments and the hypothetical ideal product including the dashed line representing $95 \%$ confidence interval for this difference.
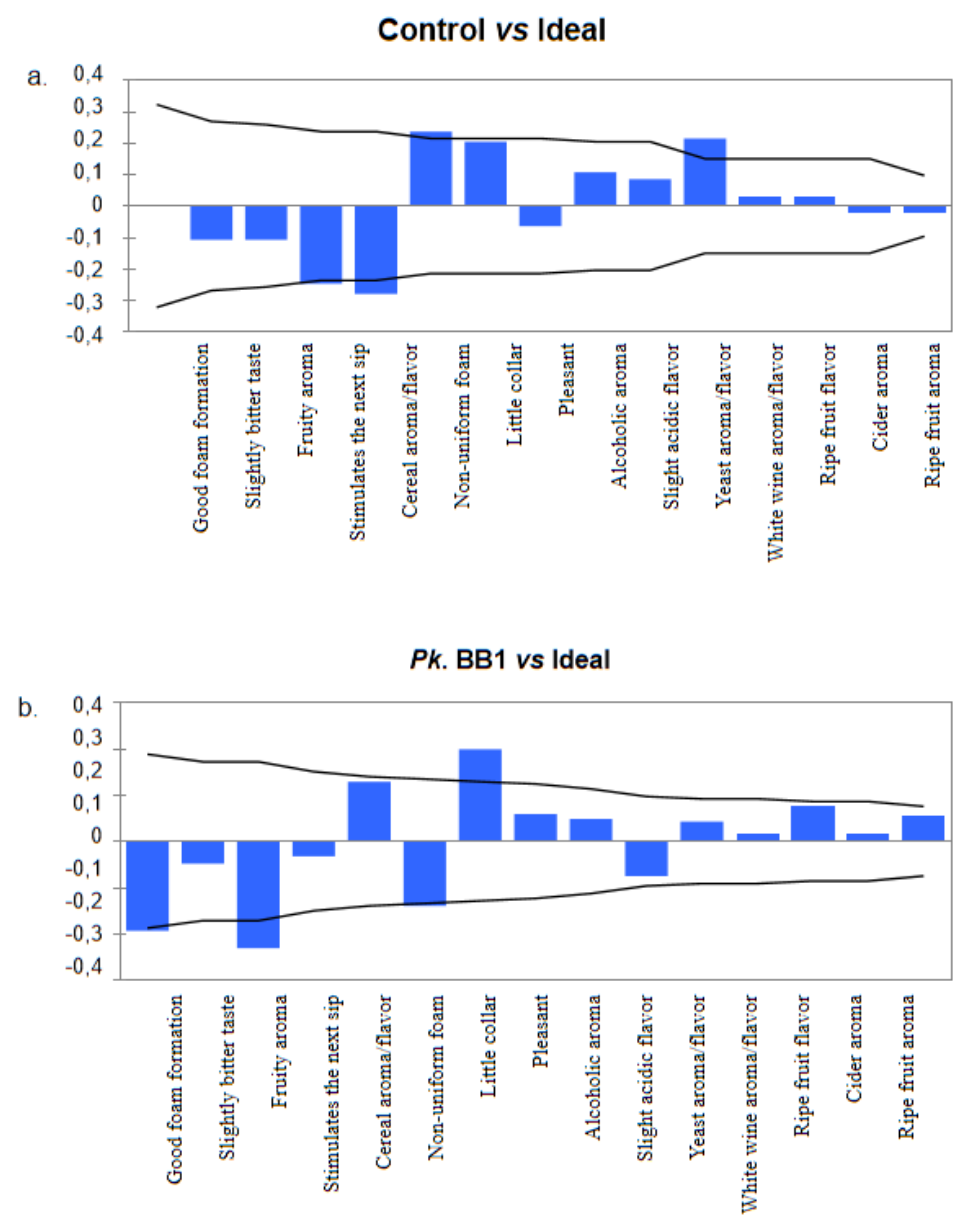

Pk. BB2 vs Ideal

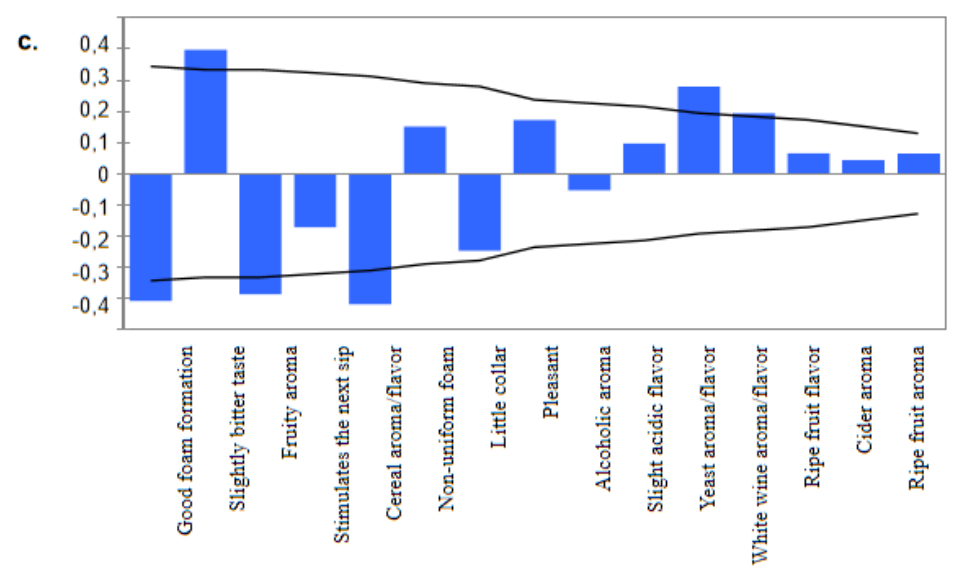


When comparing the treatments under study with the hypothetical ideal product, it is the graph in Figure 6 in shows the difference in citation rates between treatments and the ideal product. To compare individual attributes with their hypothetical ideals, the difference between the proportion of citations for the real and ideal product was determined. Figure 6 indicates the results for the control, Pk. BB1 and for Pk. BB2. The continuous line indicates the 95\% confidence interval for each individual proportion; the width of the confidence interval depends on the actual sample size (i.e. the number of consumers using the respective descriptor in one product, but not the other).

From Figure 6, it can be concluded that the three treatments contained more yeast aroma than what is considered ideal, which may be due to the production process used, in which no filtration operation is adopted for the complete removal of the yeasts, this stage that happens in the mainstream beers of the market. Furthermore, the Pk treatment BB2 had less collar than what was considered ideal. The Pk treatments BB1 and Pk. BB2 are cited less than ideally when the term descriptor is "stimulates the next sip". The terms "pleasant", "stimulates the next sip", "cereal aroma / flavorl" and "good foaming formation" were mentioned more in the ideal product than in the treatments under study.

Allied to these results, the penalty analysis can be used to identify attributes that have the greatest influence on the acceptance (or not) of the products, identifying possible reformulations. In the penalty analysis, it was observed that for the Control treatment, the descriptor "alcoholic aroma" showed a significant difference $(\mathrm{p} \leq 0.05)$ and had a negative impact of $20 \%$ (reduced by 0.974 points) the acceptance note, while the descriptor "stimulates the next sip", is an essential parameter (must have) and positively increased the note.

Although the penalty analysis for the Pk treatment. BB1 showed no significant difference (p > 0.05) in any of the parameters, the descriptors "pleasant" and "stimulates the next sip" are essential (must have) while the other parameters do not influence. The same is true for $\mathrm{Pk}$ treatment. BB2, with the difference that "non-uniform foam" is a characteristic which must be corrected.

Therefore, it is possible to summarize the change recommendations for bioaromatized beers, based on the penalty analysis performed in Table 6, below.

Table 6. Recommendations for improving bio-aromatic craft beers using Pk strains. BB1 and Pk. BB2.

Treatment
$\begin{array}{r}\text { Main Recommendations } \\ \text { "pleasant" and "stimulates the next sip" are must-have characteristics. The yeast aroma did not have an impact } \\ \text { in the acceptance, as well as the aromas alcholic/ripe fruit/fruity/cider, white whine/ripe fruit flavors and slight } \\ \text { acidic flavor }\end{array}$
"non-uniform foam" must be corrected in this treatment to enhance the sampel acceptance and "pleasant " and
"stimulates the next sip" must continue as present characteristics. The alcoholic/ ripe fruit/fruity/cider aroma,
white wine flavor and slight acidic flavor do not impact in the acceptance

Source: Authors (2021)

\section{Conclusion}

It is concluded that the group of yeast strains analyzed can be used as a producer of bioaromas such as cutlery, alcohols and carboxylic acids in the manufacture of artisanal beers in co-fermentation with commercial yeasts Saccharomyces sp, with parameters of $\mathrm{pH}, \mathrm{FG}$ and attenuation $(\%)$ considered adequate.

Most of the bioaromas produced did not interfere with beer acceptance in general, especially in the group of tasters who consume craft beer (Cluster 1), so they are more used to consuming a more aromatic and differentiated product than the commonly found in the market.

The use of the CATA methodology was important to understand the ideal product profile that consumers want, improving 
the perception of the target audience through analysis by Clusters and suggesting changes and improvements in products through the analysis of penalties, facilitating the production of beers that meet these parameters quickly and economically.

Some changes are necessary to further improve product acceptance and further studies should be carried out with these strains in order to achieve better acceptance by consumers through studies with different concentrations of the initial inoculum, the use of different types of matter - raw as different types of malts and hops, but mainly making use in different styles of beer, such as full-bodied, alcoholic beers and long-matured guard beers, such as the Belgian Lambic and Gueuse, in addition to investigating the interaction of these strains with different types of woods.

\section{Acknowledgments}

This research did not receive any specific grant from funding agencies in the public, commercial, or not-for-profit sectors.

\section{References}

Alexi, N., Nanou, E., Lazo, O., Guerrero, L., Grigorakis, K. \& Byrne, D. V. (2018). Check-All-That-Apply (CATA) with semi-trained assessors: Sensory profiles closer to descriptive analysis or consumer elicited data? Food Quality and Preference, 64, 11-20. http://dx.doi.org/10.1016/j.foodqual.2017.10.009.

Ares, G. \& Jarger, S. R. (2015). Check-all-that-apply (CATA) questions with consumers in practice: experimental considerations and impact on outcome. Rapid Sensory Profiling Techniques, 227-245. http://dx.doi.org/10.1533/ 9781782422587.2.227.

Ares, G., Barreiro, C., Deliza, R., Giménez, A. \& Gámbaro, A. (2010). Application of a check-all-that-apply question to the development of chocolate milk desserts. Journal of Sensory Studies, 55(1), 67-86. http://dx.doi.org/10.1111/j.1745-459x.2010.00290.x.

Bamforth, C. W., Russell, I., Stewart, G. (2008). Beer: A quality perspective. Academic Press. 287 p. (Handbook of Alcoholic Beverages).

Briggs, D. E., Boulton, C. A. \& Brookes, P. A. (2004). Brewing Science and Practice. Abington: Woodhead Publishing Limited, 2004.983 p.

Brunelli, L. T., Manzano, A. L. \& Venturini-Filho, W. G. (2014). Caracterização físico-química de cervejas elaboradas com mel. Brazilian Journal of Food Technology, 17(1), 19-27. https://doi.org/10.1590/bjft.2014.004.

Callaway, E. (2016). The beer geeks: a lab in Belgium is using genetics to make the perfect beer yeast. Nature, 535, $484-487$.

Camargo, J. Z., Nascimento, V. M., Stefanello, I., Silva, C. A. A., Gonçalves, F. A., Perdomo, I. C., Vilela, D. M., Simionatto, S., Pereira, R. M., Paz, M. F. Leite, R. S. R., Gelinski, J. M. L. N., Fonseca G. G. (2018). Biochemical evaluation, molecular characterization and identification of novel yeast strains isolated from Brazilian savannah fruits, chicken litter and a sugar and alcohol mill with biotechnological potential for biofuel and food industries. Biocatalysis and Agricultural Biotechnology, 16, 390-399. http://dx.doi.org/10.1016/j.bcab.2018.09.006

Canonico, L., Agarbati, A., Comitini, F. \& Ciani, M. (2016). Torulaspora delbrueckii in the brewing process: A new approach to enhance bioflavour and to reduce ethanol content. Food Microbiology, 56, 45-51. http://dx.doi.org/10.1016/j.fm.2015.12.005.

Capece, A., Romaniello, R., Siesto, G \& Romanno, P. (2018). Conventional and non-conventional yeasts in beer production. Fermentation, 4(2), 38-112. http://dx.doi.org/10.3390/fermentation4020038.

CHr. Hansen A/S. (2013). Sofie Sarens, Jan Hendrik Swiegers. Enhancement of beer flavor by a combination of Ppichia yeast and different hop varieties. US $\mathrm{n}^{\circ}$ WO2013030398A1.

Ciani, M. \& Comitini, F. (2010). Non-Saccharomyces wine yeasts have a promising role in biotechnological approaches to winemaking. Annals of Microbiology, 61(1) 25-32. http://dx.doi.org/10.1007/s13213-010-0069-5.

Conway, J. (2018). Craft beer breweries per capita in the United States in 2018, by state. Statista. Estados Unidos. https://www.statista.com/statistics/319978/craft-beer-breweries-per-capita-in-the-us-by-state/.

Coote, N. \& Kirsop, B. H. (1976). Factors responsible for the decrease in ph during beer fermentations. Journal of The Institute of Brewing, 82(3), 149-153. http://dx.doi.org/10.1002/j.2050-0416.1976.tb03739.x.

Donadini, G. \& Porretta, S. (2017). Uncovering patterns of consumers' interest for beer: a case study with craft beers. Food Research International, 91, 183198. http://dx.doi.org/10.1016/j.foodres.2016.11.043.

Elzinga, K. K. G., Tremblay, C. H., Tremblay, V. J. (2015). Craft Beer in the United States: History, Numbers, and Geography. Journal of Wine Economics, 10(3), 242-274. http://dx.doi.org/10.1017/jwe.2015.22.

Garcia, M.M.E. (2017). Produção de cerveja: Utilização de estirpes não convencionais em co-fermentação com Saccharomyces para potenciação do perfil sensory de diversos tipos de cerveja. 2017. 119 f. Dissertação (Mestrado) - Curso de Engenharia Alimentar - Processamento de Alimentos, Instituto Superior de Agronomia, Universidade de Lisboa, Lisboa. 
Gonçalves, M., Pontes, A., Almeida, P., Barbosa, R., Serra, M., Libkind, D., Hutzler, M., Gonçalves, P., Sampaio, J. P. (2016). Distinct Domestication Trajectories in Top-Fermenting Beer Yeasts and Wine Yeasts. Current Biology, 26(20), 2750-2761. http://dx.doi.org/10.1016/j.cub.2016.08.040.

Kaneda, H., Takashio, M., Tamaki, T. \& Osawa, T. (1997). Influence of ph on flavour staling during beer storage. Journal of The Institute of Brewing, 103(1), 21-23. http://dx.doi.org/10.1002/j.2050-0416.1997.tb00932.x

Klopper, W. J., Angelino, S. A. G. F., Tuning, B. \& Vermeire, H. A. (1986). Organic acids and glycerol in beer. Journal of The Institute of Brewing, 92(3), 225-228. Wiley. http://dx.doi.org/10.1002/j.2050-0416.1986.tb04405.x.

Kunze, W. (2004). Technology Brewing and Malting. (3a ed.), VLB.

Kurtzman, C., Fell, J.W., Boekhout, T. (2011). The yeasts: a taxonomic study. Elsevier, 1, $5^{\circ}$ ed.

Liobell, F., Giacalone, D., Labenne, A. \& Qannari, E. M. (2019). Assessment of the agreement and cluster analysis of the respondents in a CATA experiment. Food Quality and Preference, 77, 184-190. http://dx.doi.org/10.1016/j.foodqual.2019.05.017.

Liu, S.-Q. \& Quek, A. Y. H. (2016). Evaluation of beer fermentation with a novel yeast Williopsis saturnus. Food Technology and Biotechnology, 54(4), 403412. http://dx.doi.org/10.17113/ftb.54.04.16.4440.

Mander, L., \& Liu, H. (2010). Comprehensive natural products II: chemistry and biology. Chemistry and biology. Austin: Elsevier, 10 v.

Marcusso, E. F., Müller, C. V. (2018). Anuário da cerveja no Brasil 2018 : Crescimento e Inovação. http://www.agricultura.gov.br/vassuntos/inspecao/produtos-vegetal/pasta-publicacoes-DIPOV/anuario-da- cerveja-no-brasil-2018.

Martins, C., Brandão, T., Almeida, A. \& Rocha, S. M. (2015). Insights on beer volatile profile: Optimization of solid-phase microextraction procedure taking advantage of the comprehensive two-dimensional gas chromatography structured separation. Journal of Separation Science, 38(12), 2140- 2148. http://dx.doi.org/10.1002/jssc.201401388.

Monaco, S. M., Barda, N. B., Rubio, N. C. \& Caballero, A. C. (2014). Selection and characterization of a Patagonian Pichia kudriavzevii for wine deacidification. Journal of Applied Microbiology, 117(2), 451-464. http://dx.doi.org/10.1111/jam.12547.

Mónaco, S. M., Rodríguez, M. E., Lopes, C.A. (2016). Pichia kudriavzevii as a representative yeast of North Patagonian winemaking terroir. International Journal of Food Microbiology, 230, 31-39. http://dx.doi.org/10.1016/j.ijfoodmicro.2016.04.017.

Osburn, K., Amaral, S., Metcalf, S. R., Nickens, D. M., Rogers, C. M., Sausen, C., Caputo, R., Miller, J. Li, H., Tennessen, J. M., Bochman, M. L. (2018). Primary souring: A novel bacteria-free method for sour beer production. Food Microbiology, 70, 76-84. http://dx.doi.org/10.1016/j.fm.2017.09.007.

Paine, A. J. \& Dayan, A. D. (2001). Defining a tolerable concentration of methanol in alcoholic drinks. Human \& Experimental Toxicology, 20(11), 563-568. http://dx.doi.org/10.1191/096032701718620864.

Palmer, J. J. (2017). How To Brew: Everything You Need to Know to Brew Great Beer Every Time. (4a ed.), Boulder: Brewers Publications. 582 p.

Papazian, C. (2014). The complete joy of homebrewing. (4a ed.), Harper USA. 467 p.

Perfumer \& Flavorist (2018). The Sensory Resource for Flavor \& Fragrance Leaders: The Good Scents Company Information System. Estados Unidos. https://www.perfumerflavorist.com.

Pinu, F. R. \& Villas-Boas, S. G. (2017). Extracellular Microbial Metabolomics: The State of the Art. Metabolites, 7(3), 43. http://dx.doi.org/10.3390/metabo7030043.

Pires, E. J., Teixeira, J. A., Brányik, T. \& Vicente, A. A. (2014). Yeast: the soul of beer's aroma-a review of flavour-active esters and higher alcohols produced by the brewing yeast. Applied Microbiology and Biotechnology, 98(5), 1937-1949. http://dx.doi.org/10.1007/s00253-013-5470-0.

Pizarro, C., Pérez-Del-Notario, N., González-Sáiz, J. M. (2010). Optimisation of a simple and reliable method based on headspace solid-phase microextraction for the determination of volatile phenols in beer. Journal of Chromatography A, 121(39), 6013-6021. http://dx.doi.org/10.1016/j.chroma.2010.07.021.

Ramsey, I., Ross, C., Ford, R., Fisk, I., Yang, Q., Gomez-Lopez, J. \& Hort, J. (2018). Using a combined temporal approach to evaluate the influence of ethanol concentration on liking and sensory attributes of lager beer. Food Quality and Preference, 68, 292-303. http://dx.doi.org/10.1016/j.foodqual.2018.03.019.

Riu-Aumatell, M., Miró, P., Serra-Cayuela, A., Buxaderas, S., López-Tamames, E. (2014). Assessment of the aroma profiles of low-alcohol beers using HSSPME-GC-MS. Food Research International, 57, 196-202. http://dx.doi.org/10.1016/j.foodres.2014.01.016.

Rossi, S., Sileoni, V, Perreti, G. \& Marconi, O. (2013). Characterization of the volatile profiles of beer using headspace solid-phase microextraction and gas chromatography-mass spectrometry. Journal of The Science of Food and Agriculture, 94(5), 919- 928. http://dx.doi.org/10.1002/jsfa.6336.

Santos, S. P. (2003). Os Primórdios da Cerveja no Brasil. Cotia: Ateliê Editorial. 56 p.

Silva, G. A., Augusto, F. \& Poppi, R. J. (2008). Exploratory analysis of the volatile profile of beers by HS-SPME-GC. Food Chemistry, 111(4), 1057-1063. http://dx.doi.org/10.1016/ j.foodchem.2008.05.022.

Silva, R. O., Batistote, M., Cereda, M. P. (2011). Wild strains of fermenting yeast isolated of sugar cane juice from an alcohol distillery from Mato Grosso, Brazil. Journal of Biotechnology and Biodiversity, 3(2), 22-27. https://sistemas.uft.edu.br/periodicos/index.php/JBB/article/view/ 241/173.

Steensels, J., Verstrepen, K. J. (2014). Taming Wild Yeast: Potential of Conventional and Nonconventional Yeasts in Industrial Fermentations. Annual Review of Microbiology, 68(1), 61-80, http://dx.doi.org/10.1146/annurev-micro-091213-113025. 
Research, Society and Development, v. 11, n. 1, e17311124783, 2022

(CC BY 4.0) | ISSN 2525-3409 | DOI: http://dx.doi.org/10.33448/rsd-v11i1.24783

The Good Scents Company. (2019). The Good Scents Company Information System. http://www.thegoodscentscompany.com/search2.html.

Van Rijswijck, I. M. H., Wolkers-Rooijackers, J. C. M., Abee, T. \& Smid, E. J. (2017). Performance of non-conventional yeasts in co- culture with brewers' yeast for steering ethanol and aroma production. Microbial Biotechnology, 10(6), 1591-1602. http://dx.doi.org/10.1111/1751-7915.12717.

Varela, C. (2016). The impact of non-Saccharomyces yeasts in the production of alcoholic beverages. Applied Microbiology and Biotechnology, 100(23), 9861-9874. http://dx.doi.org/10.1007/s00253-016-7941-6.

Venturini F. W. G., Cereda, M. P. (2001). Cerveja. In: Aquarone, E., Borzani, W., Schimidell, W., Lima, U. A. Biotecnologia Industrial: Biotecnologia na Produção de Alimentos. Edgard Blucher. 4, 91-144.

Viejo, C. G., Fuentes, S., Torrico, D. D., Godbole, A. \& Dunshea, F. R. (2019). Chemical characterization of aromas in beer and their effect on consumers liking. Food Chemistry, 293, 479-485. http://dx.doi.org/10.1016/j.foodchem.2019.04.114.

Zarnkow, M. (2014). Beer. Encyclopedia of Food Microbiology. Freising, (2n. ed.), 209- 215. https://doi.org/10.1016/B978-0-12-384730-0.00393-1. 